In cooperation with the

Michigan Department of Environmental Quality

\title{
Trends in Surface-Water Quality at Selected National Stream Quality Accounting Network (NASOAN) Stations, in Michigan
}

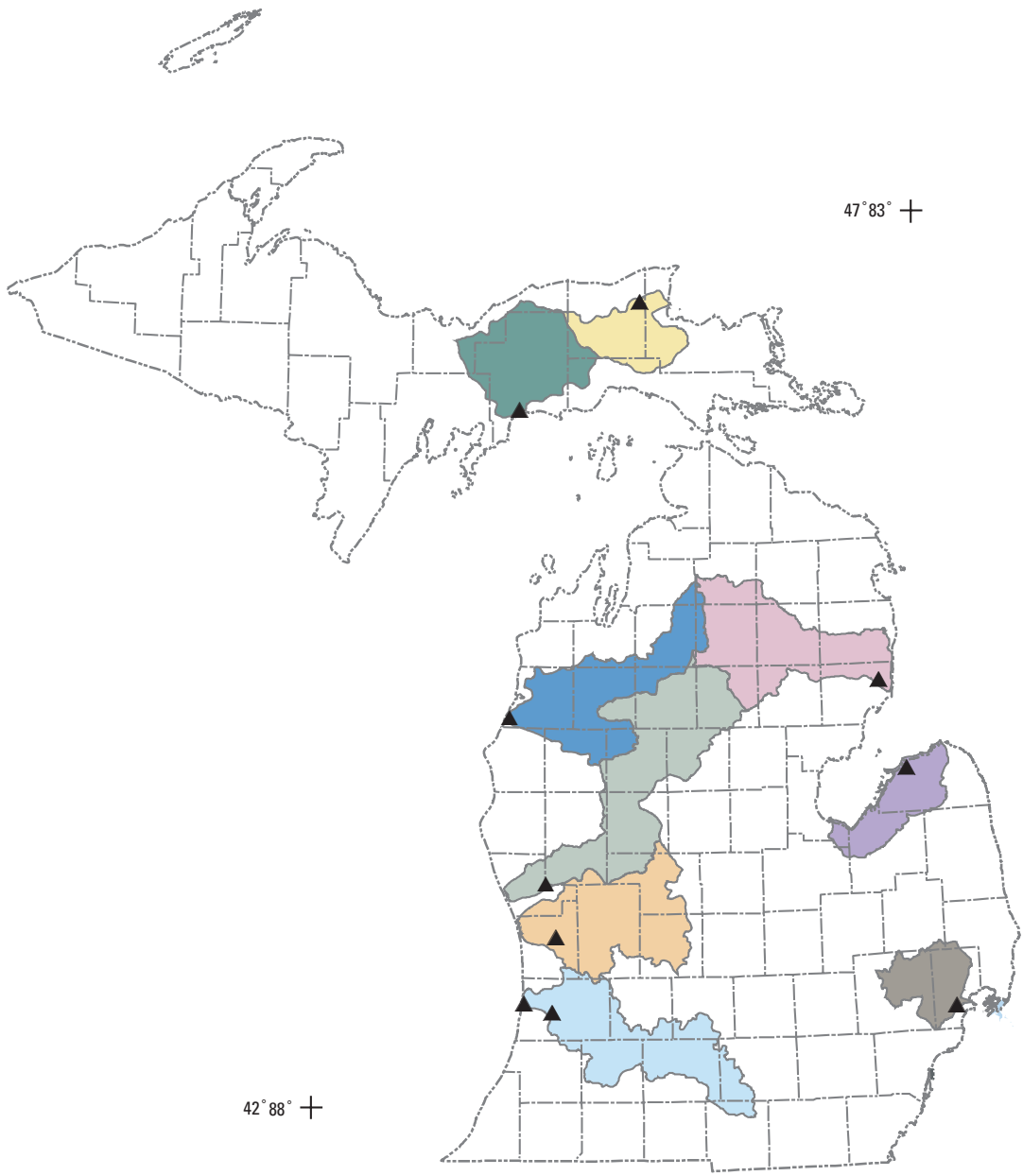

Scientific Investigations Report 2005-5158 
Cover Illustration. Map of Michigan showing watersheds analyzed for trend tests in this study. (Illustration by Richard Jodoin, U.S. Geological Survey.) 


\section{Trends in Surface-Water Quality at Selected National Stream Quality Accounting Network (NASQAN) Stations, in Michigan}

By Atiq U. Syed and Lisa R. Fogarty

Prepared in cooperation with the

Michigan Department of Environmental Quality

Scientific Investigations Report 2005-5158 


\section{U.S. Department of the Interior \\ Gale A. Norton, Secretary \\ U.S. Geological Survey \\ P. Patrick Leahy, Acting Director}

U.S. Geological Survey, Reston, Virginia: 2005

For sale by U.S. Geological Survey, Information Services
Box 25286, Denver Federal Center
Denver, CO 80225
For more information about the USGS and its products:
Telephone: 1-888-ASK-USGS
World Wide Web: http://www.usgs.gov/

Any use of trade, product, or firm names in this publication is for descriptive purposes only and does not imply endorsement by the U.S. Government.

Although this report is in the public domain, permission must be secured from the individual copyright owners to reproduce any copyrighted materials contained within this report.

Suggested citation:

Syed, A.U., Fogarty, L.R., 2005, Trends in Surface-Water Quality at Selected National Stream Quality Accounting Network (NASQAN) Stations, in Michigan: U.S. Geological Survey Scientific Investigations Report 2005-5158, 38 p. 


\section{Contents}

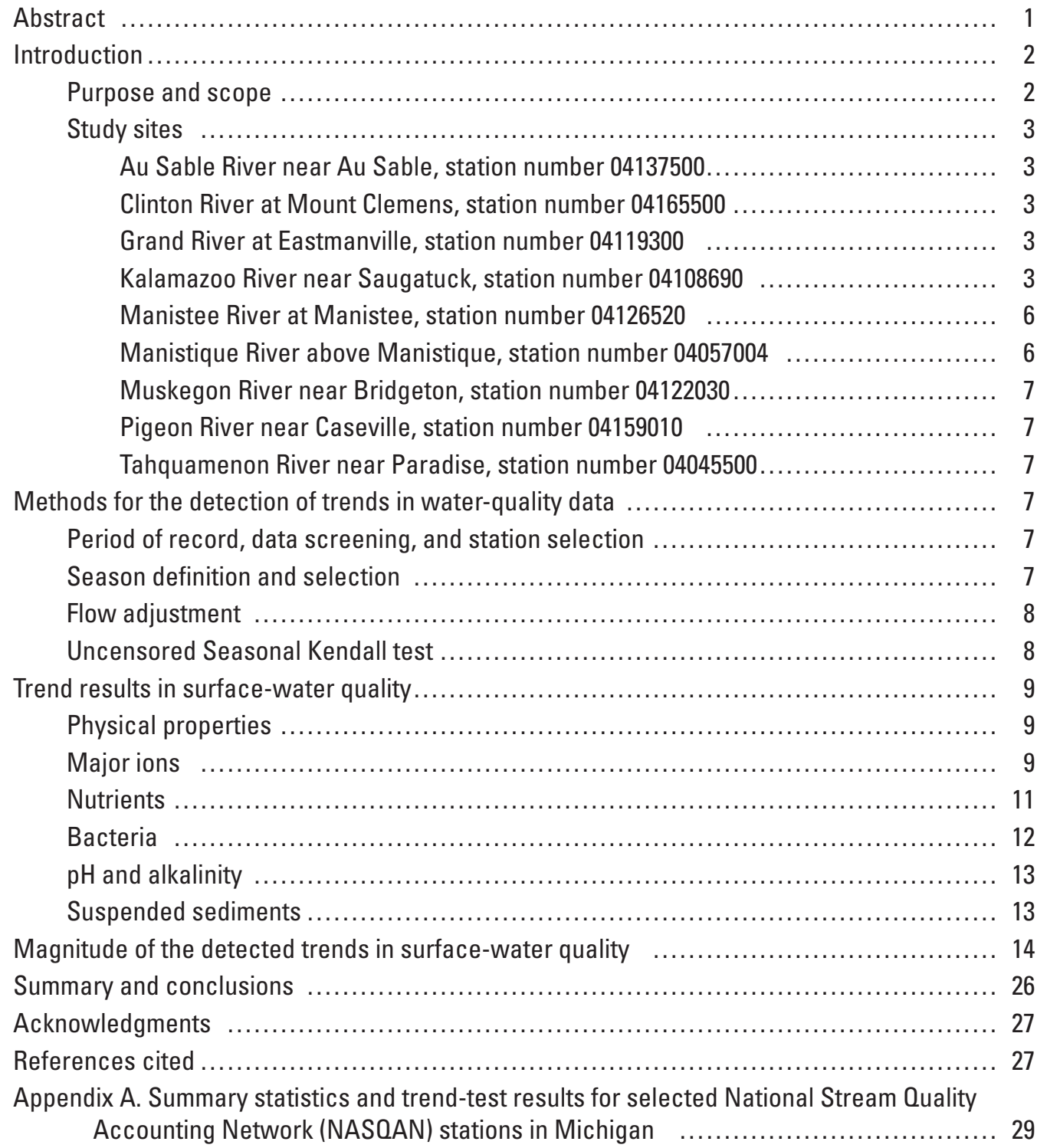

\section{Figures}

1-2. Maps showing:

1. Location of selected water-quality stations used in this study and their respective drainage basins in Michigan.

2. Location of lakes, counties, townships, and cities near selected water-quality stations in Michigan.

2-15. Graphs showing:

3. Significant trends detected in water-quality constituents at the Au Sable River Sable (04137500), Michigan 
4. Significant trends detected in water-quality constituents at the Clinton River at Mount Clemens (04165500), Michigan ....

5. Significant trends detected in water-quality constituents at the Clinton River at Mount Clemens (04135500), Michigan .

6. Significant trends detected in water-quality constituents at the Clinton River at Mount Clemens (04135500), Michigan.

7. Significant trends detected in water-quality constituents at the Grand River at Eastmanville (04119300), Michigan

8. Significant trends detected in water-quality constituents at the Kalamazoo River near Saugatuck (04108690), Michigan

9. Significant trends detected in water-quality constituents at the Manistee River at Manistee (04126520), Michigan

10. Significant trends detected in water-quality constituents at the Manistee River at Manistee (04126520), Michigan 20

11. Significant trends detected in water-quality constituents at the Manistique River above Manistique (04157004), Michigan

12. Significant trends detected in water-quality constituents at the Muskegon River near Bridgeton (04122030), Michigan

13. Significant trends detected in water-quality constituents at the Pigeon River near Caseville (04159010), Michigan

14. Significant trends detected in water-quality constituents at the Pigeon River near Caseville (04159010), Michigan

15. Significant trends detected in water-quality constituents at the Tahquamenon River near Paradise (04045500), Michigan 25

\section{Tables}

1. Percent land use of the selected National Stream Quality Accounting Network Stations (NASQAN) in Michigan, 1978 and 2001

2. Season definition based on the ESTREND program used in this study 8

3. Summary statistics and trend results for physical properties at selected National Stream Quality Accounting Network stations in Michigan

4. Summary statistics and trend results for major dissolved ions at selected National Stream Quality Accounting Network stations in Michigan 10

5. Summary statistics and trend results for nutrients at selected National Stream Quality Accounting Network stations in Michigan

6. Summary statistics and trend results for bacteria at selected National Stream Quality Accounting Network stations in Michigan

7. Summary statistics and trend results for $\mathrm{pH}$ and alkalinity at selected National Stream Quality Accounting Network stations in Michigan ... 13

8. Summary statistics and trend results for suspended sediment at selected National Stream Quality Accounting Network stations in Michigan 


\section{Conversion Factors and Abbreviations}

\begin{tabular}{lcl}
\hline Multiply & By & To obtain \\
\hline \multicolumn{3}{c}{ Area } \\
\hline acre & 4046.85 & square meter $\left(\mathrm{m}^{2}\right)$ \\
square miles $\left(\mathrm{mi}^{2}\right)$ & 2.590 & square kilometer $\left(\mathrm{km}^{2}\right)$ \\
\hline & Flow rate & \\
\hline cubic foot per second $(\mathrm{ft} 3 / \mathrm{s})$ & 0.02832 & cubic meter per second $\left(\mathrm{m}^{3} / \mathrm{s}\right)$ \\
\hline
\end{tabular}

Temperature in degree Celsius $\left({ }^{\circ} \mathrm{C}\right)$ may be converted to degrees Fahrenheit $\left({ }^{\circ} \mathrm{F}\right)$ as follows: ${ }^{\circ} \mathrm{F}=\left(1.8^{*}{ }^{\circ} \mathrm{C}\right)+32$

Temperature in degree Fahrenheit $\left({ }^{\circ} \mathrm{F}\right)$ may be converted to degree Celsius $\left({ }^{\circ} \mathrm{C}\right)$ as follows: ${ }^{\circ} \mathrm{C}=\left({ }^{\circ} \mathrm{F}-32\right) / 1.8$

Specific Conductance is given in microsiemens per centimeter at 25 degrees Celsius $\left(\mu \mathrm{S} / \mathrm{cm}\right.$ at $\left.25^{\circ} \mathrm{C}\right)$

Concentration of chemical constituents in water is given in milligrams per liter (mg/L). A milligram per liter is a unit expressing the concentration of chemical constituents in solution as weight (milligrams) of solute per unit volume (liter) of water.

Concentration of bacteria is given as cfu/ $100 \mathrm{ml}$. This pertains to the number of bacteria colonies formed from $100 \mathrm{ml}$ of the sample. 



\title{
Trends in Surface-Water Quality at Selected National Stream Quality Accounting Network (NASQAN) Stations, in Michigan
}

\author{
By Atiq U. Syed and Lisa R. Fogarty
}

\section{ABSTRACT}

To demonstrate the value of long-term, water-quality monitoring, the Michigan Department of Environmental Quality (MDEQ), in cooperation with the U.S. Geological Survey (USGS), initiated a study to evaluate potential trends in water-quality constituents for selected National Stream Quality Accounting Network (NASQAN) stations in Michigan. The goal of this study is to assist the MDEQ in evaluating the effectiveness of water-pollution control efforts and the identification of water-quality concerns.

The study included a total of nine NASQAN stations in Michigan. Approximately 28 constituents were analyzed for trend tests. Station selection was based on data availability, land-use characteristics, and station priority for the MDEQ Water Chemistry Monitoring Project. Trend analyses were completed using the uncensored Seasonal Kendall Test in the computer program Estimate Trend (ESTREND), a software program for the detection of trends in water-quality data. The parameters chosen for the trend test had (1) at least a 5-year period of record (2) about 5 percent of the observations censored at a single reporting limit, and (3) 40 percent of the values within the beginning one-fifth and ending one-fifth of the selected period. In this study, a negative trend indicates a decrease in concentration of a particular constituent, which generally means an improvement in water quality; whereas a positive trend means an increase in concentration and possible degradation of water quality.

The results of the study show an overall improvement in water quality at the Clinton River at Mount Clemens, Manistee River at Manistee, and Pigeon River near Caseville. The detected trend for these stations show decreases in concentrations of various constituents such as nitrogen compounds, conductance, sulfate, fecal coliform bacteria, and fecal streptococci bacteria. The negative trend may indicate an overall improvement in agricultural practices, municipal and industrial wastewater-treatment processes, and effective regulations.

Phosphorus data for most of the study stations could not be analyzed because of the data limitations for trend tests. The only station with a significant negative trend in total phosphorus concentration is the Clinton River at Mount Clemens. However, scatter-plot analyses of phosphorus data indicate decreasing concentrations with time for most of the study stations.

Positive trends in concentration of nitrogen compounds were detected at the Kalamazoo River near Saugatuck and Muskegon River near Bridgeton. Positive trends in both fecal coliform and total fecal coliform were detected at the Tahquamenon River near Paradise. Various different point and nonpoint sources could produce such positive trends, but most commonly the increase in concentrations of nitrogen compounds and fecal coliform bacteria are associated with agricultural practices and sewage-plant discharges.

The constituent with the most numerous and geographically widespread significant trend is $\mathrm{pH}$. The $\mathrm{pH}$ levels increased at six out of nine stations on all the major rivers in Michigan, with no negative trend at any station. The cause of $\mathrm{pH}$ increase is difficult to determine, as it could be related to a combination of anthropogenic activities and natural processes occurring simultaneously in the environment.

Trends in concentration of major ions, such as calcium, sodium, magnesium, sulfate, fluoride, chloride, 
and potassium, were detected at eight out of nine stations. A negative trend was detected only in sulfate and fluoride concentrations; a positive trend was detected only in calcium concentration. The major ions with the most widespread significant trends are sodium and chloride; three positive and two negative trends were detected for sodium, and three negative and two positive trends were detected for chloride. The negative trends in chloride concentrations outnumbered the positive trends. This result indicates a slight improvement in surface-water quality because chloride as a point source in natural water comes from deicing salt, sewage effluents, industrial wastes, and oil fields.

For other major ions, such as magnesium and potassium, both positive and negative trends were detected. These changes in trends indicate changes in surfacewater quality caused by a variety of point and non-point sources throughout Michigan, as well as natural changes in the environment.

\section{INTRODUCTION}

With over 36,000 mi of streams, surface waters are an important natural resource for the State of Michigan. Prior to the Clean Water Act of 1972 (Digest of Federal Resource laws, 1972), Michigan waters were severely affected by many different land-use activities such as urbanization, industrialization, and agricultural practices. Historically, industrial operations have left many of Michigan's waters contaminated with Poly Chlorinated Biphenyls (PCBs), solvents, metals, and other hazardous wastes. Agricultural and forestry practice has also affected waters by removing protective vegetation preventing erosion, and by introducing high levels of contaminants, such as nutrients, herbicides, and pesticides. The Clean Water Act of 1972, and its subsequent amendments, forced major changes in pollution prevention, controls, and clean-ups. The Act (1) made it unlawful for any person to discharge pollutants from a point source into navigable waters without obtaining proper permits, (2) financed municipal wastewater-treatment facilities, and (3) manages runoff pollution.

The U.S. Geological Survey (USGS) National Stream Quality Accounting Network (NASQAN) was established in 1973 to provide a national water-quality monitoring network (Ficke and Hawkinson, 1975). The design of the NASQAN program provided systematically collected water-quality data from numerous watersheds throughout the country with diverse climatic, physiographic, and cultural characteristics. The NASQAN program operated 34 water-quality stations in Michigan from 1973 to 1995 (Alexander and others, 1996). Documented information on sample collection, laboratory analysis, and quality assurance for the NASQAN program are presented in the USGS Digital Data Series publication DDS-37 (Alexander and others, 1996).

In 1998, the Water Chemistry Monitoring Project (WCMP) was established by the Michigan Department of Environmental Quality (MDEQ) in partnership with the USGS. The WCMP represented a first step towards improving water quality in Michigan since funding reductions in the mid-1990s resulted in severely restricted monitoring capabilities. The design of WCMP provides systematically collected annual water-chemistry data from stations located within the Great Lakes connecting channels, Saginaw Bay, Grand Traverse Bay, and 31 Great Lakes tributary watersheds. Annual reports, maps, as well as complete WCMP study design, are available upon request from the MDEQ or at www. michigan.gov.

To demonstrate the value of water-quality monitoring, the MDEQ in cooperation with the USGS, initiated a trend detection study to evaluate potential trends in water-quality constituents for selected NASQAN stations in Michigan. A trend in water quality is a change over time in the chemical, physical, or biological characteristics of water. Water quality is constantly changing in response to the changes in physical, chemical, and biological conditions. Changes may occur hourly, daily, seasonally, or over a period of years. Understanding water-quality trends aid in evaluating the effectiveness of water-pollution control efforts and the identification of emerging water-quality concerns. Water mangers and planners use trend information to evaluate the effectiveness of public expenditures for water-quality improvement, to assess progress towards achieving established water-quality goals, and to plan preventive actions. Therefore, long-term water-quality monitoring helps to improve management of Michigan's natural resources by characterizing surface-water quality and identifying changes in quality over time.

\section{Purpose and Scope}

The purpose of this report is to identify trends in selected water-quality constituents at nine NASQAN stations. Surface-water quality data collected in Michigan from 1973 to 1995 as part of the NASQAN program were used in this analysis. The report describes (1) the procedure for selection and preparation of data used in the trend analysis, (2) the statistical techniques used to perform the trend tests, and (3) evaluation of major constituent trends for the selected NASQAN stations in Michigan.

Detailed analyses of how these trends relate to watershed characteristics, land-use changes, population distribution, and site hydrology and geology is beyond the scope of this study. However, some supporting 
information is presented to provide a perspective on the interpretation of detected trends.

\section{Study Sites}

Site selection for this study was based on data availability, land-use characteristics, and site priority for the MDEQ, WCMP. A total of nine NASQAN stations (water-quality stations) were chosen with adequate data for trend detection (fig. 1). Station, as well as constituent selection for trend testing, is discussed in detail in the "Methods for the Detection of Trends in Water-quality Data" section of this report. A brief description of each station is given below.

\section{Au Sable River near Au Sable, station number 04137500}

The Au Sable River watershed drains an area of $1,932 \mathrm{mi}^{2}$ in north-central lower Michigan (fig. 1). The Au Sable River flows from its headwaters to Lake Michigan at Oscoda, Michigan (fig. 2). Designated as a "Natural River" by the MDEQ, the Au Sable River is known for its trout fishing. Most of the main stem of the $\mathrm{Au}$ Sable River runs through or adjacent to the Huron National Forest, an area of active canoeing. Dominated by 80 -percent forest/woodland land coverage in 1978, a 30 -percent reduction in forest/woodland and 27-percent increase in grass/shrub coverage resulted in the Au Sable River watershed by 2001 (table 1).

\section{Clinton River at Mount Clemens, station number 04165500}

The Clinton River watershed drains approximately $760 \mathrm{mi}^{2}$ in four southern Michigan counties. This drainage basin includes about 40 percent of eastern Oakland County, most of Macomb County, and small portions of southern Lapeer and St. Clair Counties (fig. 2). Clinton River and its tributaries flow through 60 rural, suburban, and urban communities with a total population of more than 1.4 million. The river's headwaters are located in Springfield and Independence Townships, and it flows into Lake St. Clair in Harrison Township (fig. 2).

In 1978, land coverage in the watershed was 36-percent urban with 28-percent agricultural (table 1). The northern portion of the watershed has remained rural with some agricultural land. The southern portion of the watershed has undergone rapid urbanization resulting in 51-percent urban land coverage in 2001 (table 1).

Although historical industrial and municipal discharges were the primary causes of environmental degradation in the Clinton River, and thus, of its designation as an Area of Concern (AOC), ongoing contamination problems are largely of nonpoint source origin (Clinton River Watershed Public Advisory Council and Michigan Department of Environemntal Quality, 1997). There are no major industrial discharges to the river or its tributaries of process water (only noncontact cooling water and stormwater), and most (though not all) municipal facilities have adequate industrial pretreatment programs and have implemented combined sewer-control plans. As such, stormwater runoff as a category is the single greatest source of water-quality degradation in the Clinton River watershed (Clinton River Watershed Public Advisory Council and Michigan Department of Environmental Quality, 1997).

\section{Grand River at Eastmanville, station number 04119300}

The Grand River is the longest river in Michigan with the headwaters beginning in Jackson County, Mich., flows north to Lansing, then north-west to Lower Michigan at Grand Haven, and then ultimately discharges into Lake Michigan (figs. 1 and 2). The approximate drainage area of Grand River is 5,572 $\mathrm{mi}^{2}$. The Grand River watershed is divided into the Upper and Lower Grand River watersheds. The Lower Grand River watershed drains an area of 3,020 $\mathrm{mi}^{2}$ and contains two urban areas, the cities of Muskegon and Grand Rapids (fig. 2). The dominant land use in the watershed is agriculture; urban land use increased in the watershed from 10 percent in 1978 to 27 percent in 2001 (table 1). Based on the landcover analysis, forested land decreased from 25 percent to 11 percent from 1978 to 2001 (table 1).

\section{Kalamazoo River near Saugatuck, station number 04108690}

Kalamazoo River watershed drains an area of 2,020 $\mathrm{mi}^{2}$. The Kalamazoo River flows through south-western Michigan discharging into Lake Michigan at Saugatuck, Michigan (figs. 1 and 2). A variety of industries are present along the Kalamazoo River such as cereal production, pharmaceuticals, automotive, and paper mills. Historically, the Kalamazoo River was used for water-intake and discharges for many of these industries. These discharges contributed to PCB, and other industrial waste contamination of the river along with sewage. Portions of the Kalamazoo River are listed as U.S. Environmental Protection Agency (USEPA) Areas of Concern (AOCs) and included in the Superfund National Priorities List (U.S. Environmental Protection Agency, 2005a). The main land coverage of the Kalamazoo River watershed has remained nearly 50-percent agricultural from 1978 to 2001 (table 1). An increase of 12-percent urban land coverage has resulted in the watershed since 1978 (table 1). 


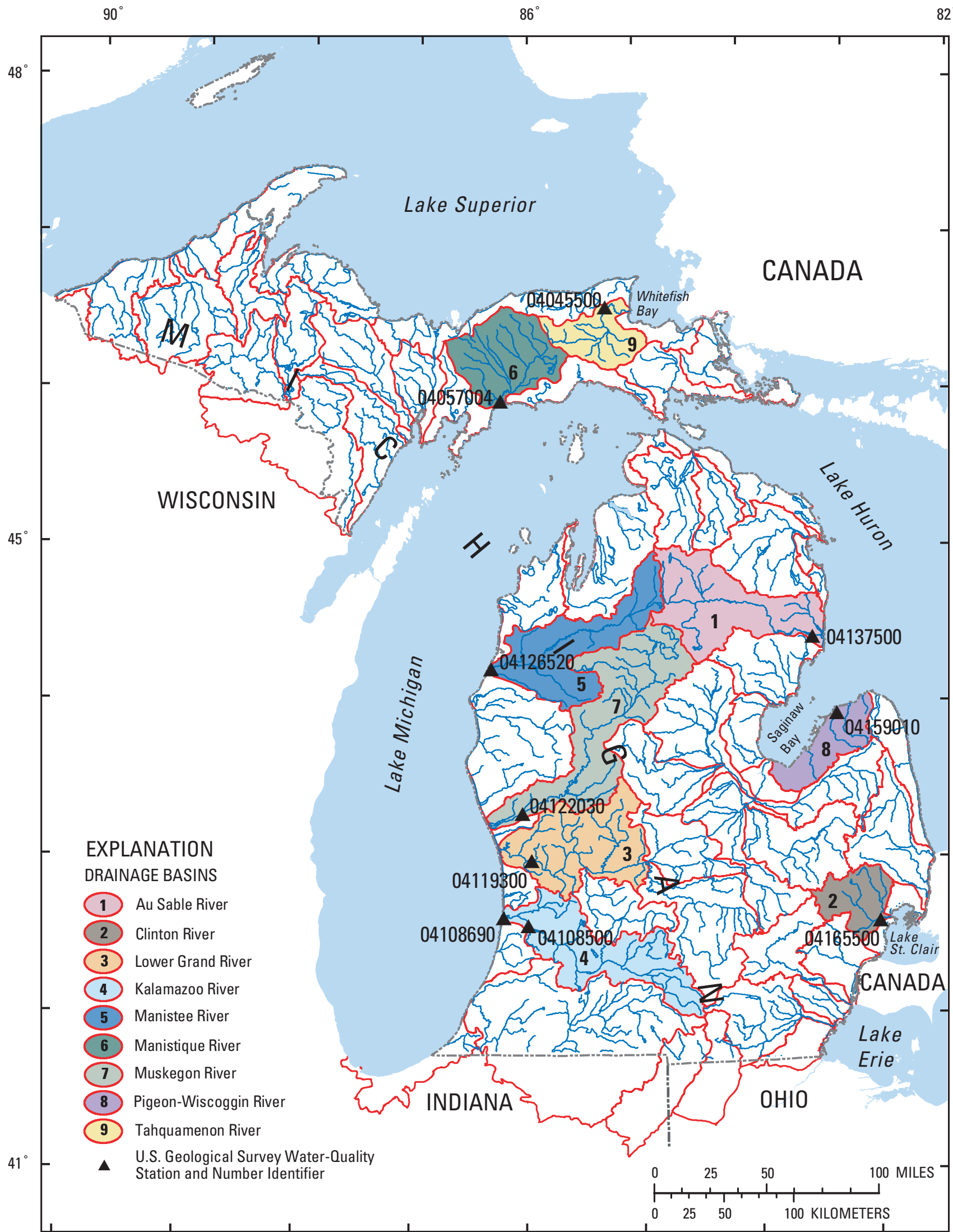

Base map from State Boundaries in the United States for BASINS, 1:2,000,000, 1998 Michigan GeoRef Projection

Figure 1. Location of selected water-quality stations used in this study and their respective drainage basins in Michigan. 


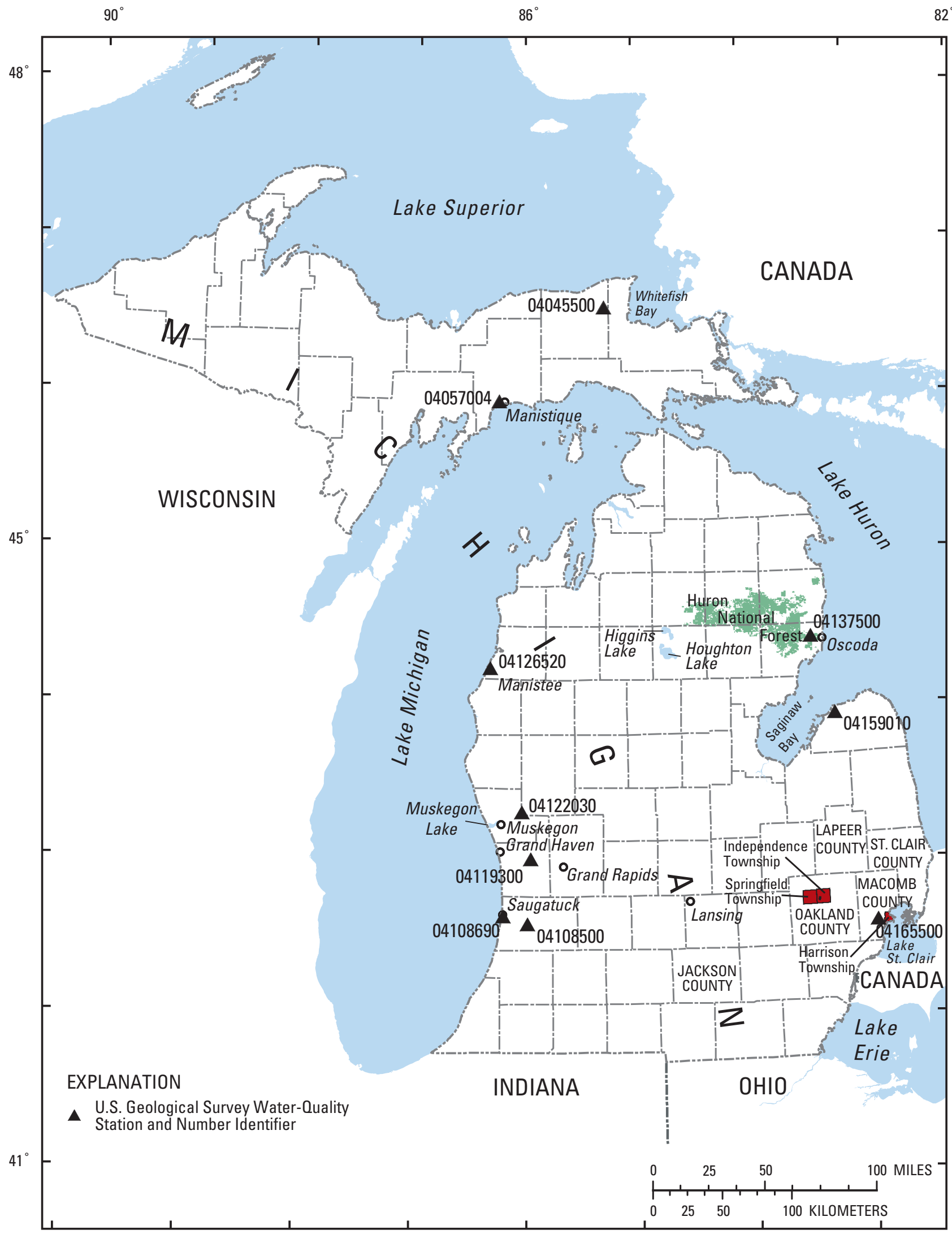

Base map from State Boundaries in the United States for BASINS, 1:2,000,000, 1998 Michigan GeoRef Projection

Figure 2. Location of lakes, counties, townships, and cities near selected water-quality stations in Michigan. 
Table 1. Percent land use of the selected National Stream Quality Accounting Network Stations (NASQAN) in Michigan, 1978 and 2001.

[USGS, U.S. Geological Survey; no., number; $\mathrm{mi}^{2}$, square miles]

\begin{tabular}{|c|c|c|c|c|c|c|c|c|}
\hline \multirow[b]{2}{*}{ USGS water-quality station name } & \multirow{2}{*}{$\begin{array}{c}\text { USGS } \\
\text { water-quality } \\
\text { station no. }\end{array}$} & \multirow[b]{2}{*}{$\begin{array}{l}\text { Drainage } \\
\text { area }\left(\mathrm{mi}^{2}\right)\end{array}$} & \multicolumn{6}{|c|}{ Percent Land Cover in 1978} \\
\hline & & & Urban & Agricultural & $\begin{array}{l}\text { Grass/ } \\
\text { Shrub }\end{array}$ & $\begin{array}{c}\text { Forest/ } \\
\text { Woodland }\end{array}$ & Water & Wetlands \\
\hline Clinton Rive at Mt. Clemens & 04165500 & 760 & 36 & 28 & 19 & 11 & 3 & 3 \\
\hline Grand River near Eastmanville & 04119300 & 3,020 & 10 & 50 & 10 & 25 & 2 & 3 \\
\hline Manistee River at Manistee & 04126520 & 1,780 & 2 & 11 & 10 & 73 & 1 & 3 \\
\hline Manistique River above Manistique & 04057004 & 1,461 & 1 & 1 & 5 & 70 & 5 & 18 \\
\hline Muskegon River near Bridgeton & 04122030 & 2,723 & 4 & 23 & 10 & 54 & 4 & 5 \\
\hline Pigeon River near Caseville & 04159010 & 136 & 2 & 86 & 2 & 8 & 1 & 1 \\
\hline
\end{tabular}

\begin{tabular}{|c|c|c|c|c|c|c|c|c|}
\hline USGS water-quality station name & $\begin{array}{c}\text { USGS } \\
\text { water-quality } \\
\text { station no. }\end{array}$ & $\begin{array}{l}\text { Drainage } \\
\text { area }\left(\mathrm{mi}^{2}\right)\end{array}$ & \multicolumn{6}{|c|}{ Percent Land Cover in 2001} \\
\hline Clinton Rive at Mt. Clemens & 04165500 & 760 & 51 & 25 & 13 & 9 & 2 & 0 \\
\hline Grand River near Eastmanville & 04119300 & 3,020 & 27 & 47 & 12 & 11 & 1 & 1 \\
\hline Manistee River at Manistee & 04126520 & 1,780 & 9 & 12 & 32 & 45 & 1 & 1 \\
\hline Manistique River above Manistique & 04057004 & 1,461 & 3 & 1 & 16 & 60 & 5 & 15 \\
\hline Muskegon River near Bridgeton & 04122030 & 2,723 & 12 & 22 & 25 & 36 & 4 & 1 \\
\hline Pigeon River near Caseville & 04159010 & 136 & 15 & 77 & 2 & 4 & 1 & 1 \\
\hline
\end{tabular}

\section{Manistee River at Manistee, station number 04126520}

The Manistee River watershed drains an area of 1,780 $\mathrm{mi}^{2}$ in North-Western Lower Michigan (fig. 1). The Manistee River flows to Lake Michigan at Manistee, Mich. Numerous logging activities are present in the watershed. There has been a 28-percent decrease in the forest/woodland land coverage in the watershed from 1978 to 2001 (table 1). The watershed contains approximately 10-percent agriculture land during this period. Urban land has increased 7 percent from 1978 to 2001 (table 1).

\section{Manistique River above Manistique, station number 04057004}

The Manistique River watershed drains an area of 1,461 mi2. The Manistique River flows southwest through the central Upper Peninsula, discharging into Lake Michigan at Manistique (figs. 1 and 2). Forest/ woodland is the dominant land use in the Manstique River watershed. There has been a 10-percent decrease in forest/woodlands and an 11-percent increase in grass/shrubs from 1978 to 2001 (table 1). Little urbanization has occurred in the watershed. Urban areas have increased from 1 to 3 percent from 1978 to 2001 (table 1). 
Muskegon River near Bridgeton, station number 04122030

The Muskegon River watershed is one of the largest watersheds in Michigan (figs. 1 and 2), draining about 2,723 $\mathrm{mi}^{2}$. Located in north-central Michigan, the Muskegon River flows from its headwaters at Houghton and Higgins Lakes, to Muskegon Lake and eventually out into Lake Michigan (figs. 1 and 2). Forest/woodland covers most of the watershed; however, between 1978 and 2001, there was an 18-percent decrease in the forest/ woodland land coverage. Urban areas increased by 8 percent from 1978 to 2001 (table 1).

\section{Pigeon River near Caseville, station number 04159010}

Located in the northern thumb area of the Lower Peninsula (figs. 1 and 2), the Pigeon River watershed drains an area of $136 \mathrm{mi}^{2}$. The Pigeon River flows northward and discharges into the Saginaw Bay (figs. 1 and 2). Agriculture has remained the dominant land use in the watershed; however, urban land use increased 13 percent from 1978 to 2001 (table 1). Drained by subsurface tiles directly into streams or into surface drains that lead to streams, agricultural practices appreciably affects water quality in the watershed.

\section{Tahquamenon River near Paradise, station number 04045500}

The Tahquamenon River watershed drains an area of 2,024 $\mathrm{mi}^{2}$. The Tahquamenon River flows northeast through the northeastern section of the Upper Peninsula, discharging into Lake Superior White Fish Bay (figs. 1 and 2). The Tahquamenon River watershed is primarily forest/woodland with little urban land (table 1). Wetlands covered 14- and 13-percent of the watershed in 1978 and 2001, respectively. Tannic acid leaching from cedar tree bark in the wetland tributaries to the river has caused a light-brown coloring of the river waters.

\section{METHODS FOR THE DETECTION OF TRENDS IN WATER-OUALITY DATA}

The suitability of data for trend testing at an individual water-quality station is affected by the samplecollection schedule, sample-collection methods, analytical methods, and period of record. These factors were evaluated in the station selection process for this study. Besides data screening, the statistical procedure used for trend detection should not be affected by (1) the non-normal distribution of data, (2) seasonal variability, (3) missing values, (4) less than values, (5) variability related to discharge, and (6) outliers. The use of conventional parametric statistical procedures, which could be adversely affected by these factors, could produce errors in water-quality trend analysis. Therefore, the non-parametric uncensored Seasonal Kendall test in the Estimate Trend (ESTREND; Schertz and other, 1991) program was selected for the detection of trends in this study. The Seasonal Kendall test and associated procedures are not affected by non-normal data distribution, large seasonal variability, values below the detection limit, missing values, and outliers. Associated flow-adjustment procedures account for concentration variability related to discharge by defining a relation between concentration and discharge (Hirsch and others, 1981). Hirsch and others (1981) found that non-parametric trend test performed significantly better than its parametric counterparts for data sets with non-normal statistical characteristics.

A brief description of the period of record and data screening, season selection, flow adjustment, and uncensored Seasonal Kendall test is given in the sections below.

\section{Period of Record, Data Screening, and Station Selection}

The period of record for each NASQAN station varies (appendix A, tables A-1 to A-9); therefore, the period of record for trend analysis was chosen based on the study period of the NASQAN project for that station. The criteria used to determine which stations to include in the trend analysis for the selected period of record for a particular constituent are as follows (modified from Schertz and others, 1991).

(1) The period of record had to be at least 5 years.

(2) Less than 5 percent of the observations censored at a single reporting limit.

(3) At least 40 percent of the values had to be within the beginning one-fifth and ending one-fifth of the selected period.

On the basis of these criteria, 9 stations with approximately 28 constituents each were chosen for trend analysis. The properties and constituents selected for these nine stations represent the major categories of water-quality data from which the long-term changes and effects could be identified. Some of the selected constituents could not be tested for trends because of insufficient data points.

\section{Season Definition and Selection}

Water-quality constituents often vary seasonally. Seasonality may mean a source of variability that pre- 
vents the detection of trends (Schertz and others, 1991). A parametric approach for removal of the effects of seasonality in water-quality data is to include a cyclical function as an explanatory variable in a regression equation that relates water-quality data to time (Schertz and Hirsch, 1985).

The ESTREND program contains an automated procedure for determining the best seasonal choice for each constituent for a particular station (Schertz and others, 1991). The program combines the suggested season definition for the beginning 20 percent and ending 20 percent of the record and compares it to the middle 60 percent of the record. The selection procedure emphasizes the beginning and ending parts of the water-quality record; this emphasis ensures that the data adequately span the period of interest. Data gaps in the middle years of the record have less effect on the performance of the statistical procedures than gaps at the beginning or end of the record (Schertz and others, 1991). In case of multiple data values within season, the value that is closest to the midpoint of the season paired with the discharge (where applicable) is selected by the program to represent the season (Schertz and others, 1991).

In this study, 2, 3, 4, 6, or 12 possible seasons per year were present. The months included in each seasonal definition are shown in table 2 . The season definition recommended for the beginning and ending parts of the record were used to define season for each station and constituent. The sampling frequency of a constituent may vary from station to station, and, consequently, the season definition for a constituent may vary from station to station.

Table 2. Season definition based on the ESTREND program used in this study.

\begin{tabular}{|c|c|}
\hline Number of seasons per year & Months included \\
\hline 2 & $\begin{array}{l}\text { April-September; } \\
\text { October-March }\end{array}$ \\
\hline 3 & $\begin{array}{l}\text { March-June; July-October; } \\
\text { November-February }\end{array}$ \\
\hline 4 & $\begin{array}{l}\text { January-March; April-June; } \\
\text { July-September; } \\
\text { October-December }\end{array}$ \\
\hline 6 & $\begin{array}{l}\text { January-February; March-April; } \\
\text { May-June; July-August; } \\
\text { September-October; } \\
\text { November-December }\end{array}$ \\
\hline 12 & $\begin{array}{l}\text { January; February; March; April; } \\
\text { May; June; July; August; } \\
\text { September; October; November; } \\
\text { December }\end{array}$ \\
\hline
\end{tabular}

\section{Flow Adjustment}

Typically, the concentration of a given constituent is related to streamflow (discharge). The concentration of many dissolved water-quality constituents generally decreases as discharge increases because of dilution. On the other hand, the concentration of suspended sediments increases with an increase in discharge because of the transport of particulates by runoff. Therefore, a large part of the variance of constituent concentrations may be a result of the variation in the associated discharges (Schertz and others, 1991). Some constituents may show a combination of both effects. The removal of streamflow as a source of variance from the data makes trend-testing techniques more powerful by increasing the probability of detecting a trend, if present, and decreases the chances of detecting trends when it is only an artifact of trend in the associated discharges.

A flow-adjustment procedure in the ESTREND program discussed by Schertz and others (1991) was used for this study. The ESTREND program removes the effects of discharge on constituent concentrations by computing a time series of flow-adjusted concentrations (FAC) and testing this time series for trend. In statistical terms, the FAC is a residual and is defined as the actual constituent concentration minus the predicted concentration. The predicted concentration is computed from an equation describing the discharge-constituent relation (Schertz and others, 1991). The ESTREND package contains an automated procedure that selects the regression model "best fit" from 15 different models. The models are both linear and non-linear, and the model selected is based upon the residuals having the lowest variation. In cases where the regression models could not be used because a good fit was not possible (regression assumptions were violated), the LOWESS (locally weighted regression smoothing function) smoothing function was used to improve the fit.

\section{Uncensored Seasonal Kendall Test}

The statistical procedure used to detect trends for this study is the uncensored Seasonal Kendall test in the ESTREND program. The Seasonal Kendall test is a non-parametric test for monotonic trend in water quality (Hirsch and others, 1981). The magnitudes of the data in favor of the relative values or ranks of the data are ignored in the test, and the effects of seasonal variability in water-quality data are removed by restricting comparisons between pairs of data values to those values that are from the same season. The test makes all possible pairwise comparisons of a time-ordered set of water-quality values. If a later value (in time) is larger, a plus is recorded; if a later value is smaller, a minus is recorded. The test statistic is computed as the differ- 
ence between the total number of pluses and the total number of minuses in the record. As the deviation of the test statistic from zero becomes larger, the likelihood of trend in the data is greater. For each water-quality record, a measure of the likelihood of trend, the p-value, is obtained from the standard normal distribution. The censored values are assigned one-half of their reporting limit. In the uncensored Seasonal Kendall test, waterquality records with more than about 5 percent of the observations censored at a single reporting limit were analyzed.

A trend in this study is defined as a one-directional (monotonic) change over time. A trend is considered to be statistically significant if the attained significance level of the trend test for a constituent is less than or equal to 0.05 . The attained significance level, or pvalue, is the probability that a detected trend resulted from a chance arrangement of the data rather than from an actual change in constituent concentration.

\section{TREND RESULTS IN SURFACE-WATER OUALITY}

Statistically significant water-quality trends for 9 NASQAN stations, each with approximately 28 constituents, are summarized in tables 3-8. In this study, a negative trend indicates a decrease in concentration of a particular constituent, which generally mean an improvement in water quality; whereas a positive trend indicates an increase in concentration and a possible degradation in water quality. Significant trends detected during the study only include constituents with flow-adjusted concentration. Details of trend results for each station are provided in appendix A at the back of the report. These results include period of record, number of observations, maximum values, minimum values, median, percentiles, and p-values.

\section{Physical Properties}

Trends were analyzed for three physical properties: temperature, specific conductance, and turbidity. Temperature is important for maintaining dissolved oxygen concentrations necessary for normal growth of aquatic plants and animals. Specific conductance is an indirect measure of the amount of dissolved matter in water. In general, the higher the concentration of ions, the greater the conductivity of the solution. Turbidity is a measure of the clarity of water, and is affected by suspended particles, dissolved matter, biological material, and color.

The only significant trend detected in physical properties is for specific conductance at the Pigeon River near Caseville station (fig. 1). No trends were detected in temperature or turbidity at any of the nine study stations.

\section{Major lons}

Major dissolved ions and related constituents analyzed for trend in this study include dissolved calcium, magnesium, potassium, sodium, chloride, sulfate, fluoride, and silica. Trend results for major ions are shown in table 4.

The most numerous trends detected in major ions were in dissolved sodium and chloride concentrations. A total of three positive and two negative trends were detected in dissolved sodium concentrations, and three negative and two positive trends were detected in dissolved chloride concentrations. Positive trends in sodium concentration were detected at the Grand River at Eastmanville, Manistique River above Manistique, and the Tahquamenon River near Paradise stations; and negative trends were detected at the Manistee River at Manistee and Pigeon River near Caseville stations. Similarly, a positive trend in chloride concentrations was detected at the Au Sable River near Au Sable and the

Table 3. Summary statistics and trend results for physical properties at selected National Stream Quality Accounting Network stations in Michigan.

[USGS, U.S. Geological Survey; 04159010 (Pigeon River near Caseville); no., number; Max., maximum value; Min., minimum value; $\mu$ S/cm, microsiemens per centimeter; -, negative trend]

\begin{tabular}{|c|c|c|c|c|c|c|c|c|c|c|c|}
\hline \multirow{2}{*}{$\begin{array}{l}\text { USGS water-quality } \\
\text { station no. }\end{array}$} & \multirow{2}{*}{$\begin{array}{l}\text { Constituents } \\
\text { and units }\end{array}$} & \multirow{2}{*}{$\begin{array}{l}\text { Period of } \\
\text { record }\end{array}$} & \multirow{2}{*}{$\begin{array}{c}\text { No. of } \\
\text { observations }\end{array}$} & \multirow{2}{*}{$\begin{array}{l}\text { Mean } \\
\text { value }\end{array}$} & \multicolumn{5}{|c|}{ Percentile Values } & \multirow[b]{2}{*}{ p-value } & \multirow[b]{2}{*}{ Trend } \\
\hline & & & & & Max. & 75 & Median & 25 & Min. & & \\
\hline 04159010 & $\begin{array}{l}\text { Specific Conductance } \\
(\mu \mathrm{S} / \mathrm{cm})\end{array}$ & $1978-93$ & 86 & 807 & 1230 & 902 & 800 & 724 & 214 & 0.024 & - \\
\hline
\end{tabular}


Table 4. Summary statistics and trend results for major dissolved ions at selected National Stream Quality Accounting Network stations in Michigan.

[USGS, U.S. Geological Survey; 04137500 (Au Sable River near Au Sable), 04165500 (Clinton River at Mount Clemens), 04119300 (Grand River at Eastmanville), 04126520 (Manistee River at Manistee), 04057004 (Manistique River above Manistique), 04122030 (Muskegon River near Bridgeton), 04159010 (Pigeon River near Caseville); no., number; Max., maximum value; Min., minimum value; mg/L, milligrams per liter; -, negative trend; +, positive trend]

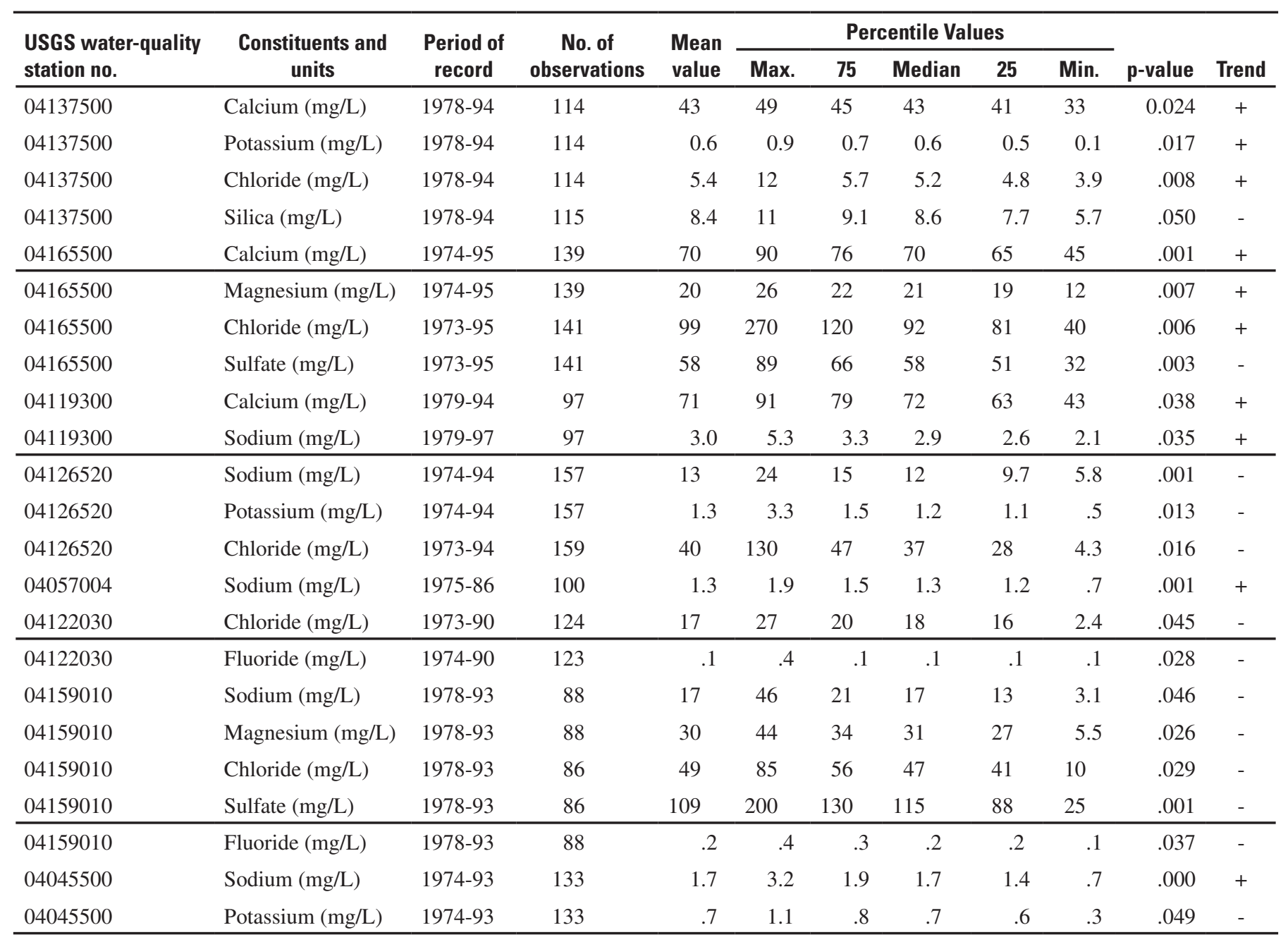

Clinton River at Mount Clemens; and negative trends were detected at the Manistee River at Manistee, Muskegon River near Bridgeton, and Pigeon River near Caseville stations (fig. 1).

Significant negative trends in sulfate concentration were detected at the Clinton River at Mount Clemens, Grand River at Eastmanville, and Pigeon River near Caseville stations. No significant trend in sulfate concentration was detected at the remaining six stations. Sulfate occurs naturally in water. Sulfate enters water from soils rock formations. Sulfate concentrations may be increased by municipal and industrial waste discharges and atmospheric deposition. Health concerns regarding sulfate in drinking water have been raised because of reports that diarrhea may be associated with the ingestion of water containing high sulfate concentrations (U.S. Environmental Protection Agency, 2005b).

Trend in concentrations of other major ions, such as calcium, magnesium, potassium, and silica, are detected in most of the study stations. Positive trend in calcium concentrations are detected at three out of nine stations with no negative trend at the remaining six stations. The stations with positive trends include the Au Sable River near Au Sable, Clinton River at Mount Clemens, and Grand River at Eastmanville.

A single positive and a single negative trend in magnesium concentration were detected at Clinton River at Mount Clemens and the Pigeon River near Caseville stations, respectively. One positive (Au Sable River near Au Sable) and two negative trends (Manistee River 
at Manistee and Tahquamenon River near Paradise) in potassium concentration were detected. A negative trend in silica concentration was detected at the Au Sable River near Au Sable; this trend is the only discernable trend for silica. Calcium, magnesium, and silica are important components of common rock types in Michigan.

Significant negative trend in fluoride concentration were detected at the Muskegon River near Bridgeton and Pigeon River near Caseville. The remaining seven stations showed no trends in fluoride concentration.

\section{Nutrients}

Nitrogen and phosphorus are important component of plants and animals. Waste matter produced by living organism, and material derived from their decomposition, are major sources of these elements in freshwater systems. Natural organic material, domestic industrial wastewater, agricultural and residential fertilizer, animal wastes, and combustion by products in the atmosphere contribute nitrogen and phosphorus to freshwater. A common nitrogen forms in streams include organic nitrogen, ammonia nitrogen, nitrate, and nitrite nitrogen. Common phosphorus form in the environment includes phosphate. Nitrogen and phosphorus transformations from one form to another can occur as a result of biological and chemical processes.

The station with the largest number of significant negative trends in nitrogen compounds was the Clinton River at Mount Clemens. Decreasing concentration of nitrogen compounds at this station include total ammonia, total ammonia plus organic nitrogen, total nitrogen, total organic nitrogen, and dissolved nitrite plus nitrate (mg/L as nitrogen) (table 5). Pigeon River near Caseville was the only other station with a negative trend in nitrogen compounds, such as total ammonia.

Table 5. Summary statistics and trend results for nutrients at selected National Stream Quality Accounting Network stations in Michigan.

[USGS, U.S. Geological Survey; 04165500 (Clinton River at Mount Clemens), 04108690 (Kalamazoo River near Saugatuck), 04122030 (Muskegon River near Bridgeton), 04159010 (Pigeon River near Caseville); no., number; Max., maximum value; Min., minimum value; mg/L, milligrams per liter; -, negative trend; + , positive trend]

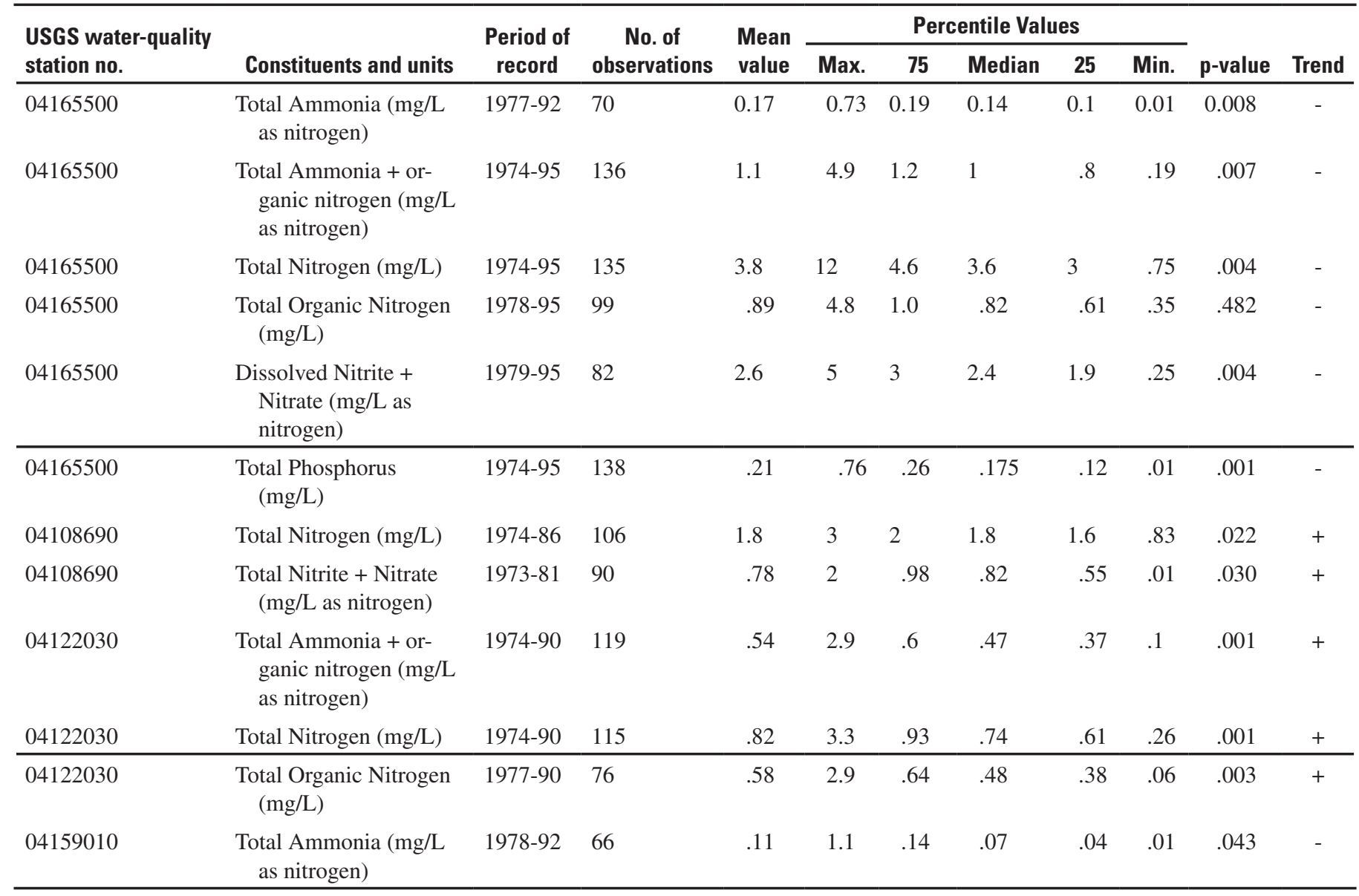


Significant positive trends (increasing concentrations) in nitrogen compounds were detected at the Kalamazoo River near Saugatuck and at the Muskegon River near Bridgeton. The Kalamazoo River near Saugatuck station showed positive trends in concentrations of total nitrogen and total nitrite plus nitrate $(\mathrm{mg} / \mathrm{L}$ as nitrogen). The Muskegon River near Bridgeton station showed positive trends in concentrations of total ammonia plus organic nitrogen, total nitrogen, and total organic nitrogen.

Phosphorus data for most of the selected stations have 20 percent of the concentration data reported at less than the analytical detection limit with many stations having more than one censoring level. This condition is a limiting factor for detecting trends in surface-water quality constituents using the uncensored Seasonal Kendall test, and, therefore, the phosphorus data were not tested for trend. However, scatter-plot analyses of phosphorus data indicate decreasing phosphorus concentration for most of the study stations. The Clinton River at Mt. Clemens was the only station with a significant negative trend in total phosphorus concentration. The Muskegon River near Bridgeton also showed decreasing total phosphorus concentrations, but this cannot be considered a significant trend because the $\mathrm{p}$-value is 0.07 (appendix A, table A-7).

\section{Bacteria}

Fecal coliform bacteria and fecal streptococci bacteria are groups of bacteria commonly associated with fecal contamination. Historically, the concentration of these organisms in the environment was used to indicate fecal contamination of humans or animals. The presence of these organisms indicated a potential health risk associated with pathogenic bacteria that might also be present in the fecal waste. During the time period of the NASQAN sampling, fecal coliforms and fecal streptococci were also collected and measured. The methods of analysis for these two groups changed in 1976. For the trend analysis study, only those samples collected after October 1976 were included. However, for sites in which there were pre-1976 data, all data were combined and called "total fecal coliforms" or "total fecal streptococci". In 1976, the USEPA recommended fecal coliform bacteria concentrations not to exceed a geometric mean of 200 colonies per $100 \mathrm{ml}$ of water. For recreational water, the USEPA in 1986 revised their recommendation for measuring water quality to include the use of E. coli (a member of the fecal coliform group) and/or enterococci (a sub-group of the fecal streptococci), and discouraged the use of fecal coliform and fecal streptococci (Environmental Protection Agency, 1986).

Bacteria samples analyzed for trends in this study include fecal coliform, total fecal coliform, fecal streptococci, and total fecal streptococci. Significant trends were detected at six sites for bacteria; these results are shown in table 6.

Negative trends in fecal coliform, total fecal coliform, fecal streptococci tests, and total fecal streptococci were detected at the Manistee River at Manistee. Positive trends in fecal coliform and total fecal coliform were detected at the Tahquamenon River near Paradise station. The remaining stations showed no significant trends in bacteria tests.

Table 6. Summary statistics and trend results for bacteria at selected National Stream Quality Accounting Network stations in Michigan.

[USGS, U.S. Geological Survey; 04126520 (Manistee River at Manistee), 04045500 (Tahquamenon River near Paradise); no., number; Max., maximum value; Min., minimum value; cfu/100 ml, colony forming units per hundred milliliters of the sample; -, negative trend; +, positive trend]

\begin{tabular}{|c|c|c|c|c|c|c|c|c|c|c|}
\hline \multirow{2}{*}{$\begin{array}{l}\text { USGS water-quality } \\
\text { station no. }\end{array}$} & \multirow[b]{2}{*}{ Constituents and units } & \multirow{2}{*}{$\begin{array}{l}\text { Period of } \\
\text { record }\end{array}$} & \multirow{2}{*}{$\begin{array}{c}\text { No. of } \\
\text { observations }\end{array}$} & \multicolumn{5}{|c|}{ Percentile Values } & \multirow[b]{2}{*}{ p-value } & \multirow[b]{2}{*}{ Trend } \\
\hline & & & & Max. & 75 & Median & 25 & Min. & & \\
\hline 04126520 & $\begin{array}{l}\text { Fecal Coliform } \\
\quad(\mathrm{cfu} / 100 \mathrm{ml})\end{array}$ & 1976-94 & 125 & 1200 & 260 & 130 & 43 & 1 & 0.000 & - \\
\hline 04126520 & $\begin{array}{l}\text { Total Fecal Coliform } \\
\quad(\mathrm{cfu} / 100 \mathrm{ml})\end{array}$ & 1976-94 & 147 & 1200 & 245 & 120 & 46.5 & 1 & .001 & - \\
\hline 04126520 & $\begin{array}{l}\text { Total Streptococci } \\
\quad(\mathrm{cfu} / 100 \mathrm{ml})\end{array}$ & 1974-94 & 156 & 3000 & 81.5 & 48 & 20 & 0 & .040 & - \\
\hline 04045500 & $\begin{array}{l}\text { Fecal Coliform } \\
\quad(\mathrm{cfu} / 100 \mathrm{ml})\end{array}$ & $1976-93$ & 104 & 280 & 22 & 7.5 & 4 & 1 & .034 & + \\
\hline
\end{tabular}




\section{pH and alkalinity}

$\mathrm{pH}$ is a measure of the activity of the hydrogen ion $(\mathrm{H}+)$ and is represented by the negative logarithm to the base 10 (Snoeyink and others, 1998). Many precipitation, dissolution, oxidation-reduction and complexation reactions are determined by the value of $\mathrm{pH}$ in aqueous solutions. $\mathrm{pH}$ is affected by temperature; by reactions of dissolved carbon dioxide with water; by reactions in which solid materials are dissolved, precipitated, or oxidized; and by the photosynthetic activity of aquatic organisms, which take up dissolved carbon dioxide during the day and release it at night.

Significant positive trend in $\mathrm{pH}$ levels were detected at six out of nine stations on all the major rivers in Michigan. No negative trends in $\mathrm{pH}$ levels were detected at any stations. The stations showing increases in $\mathrm{pH}$ levels are Clinton River at Mount Clemens (04165500), Grand River at Eastmanville (04119300), Manistique River above Manistique (04057004), Manistee River at Manistee (041265200, Pigeon River near Caseville (04159010), and Tahquamenon River near Paradise (04045500). The positive trend in all the stations is within a standard unit $\mathrm{pH}$ range. The tendency of natural water to remain within a relatively narrow band of hydrogenion activity is due to the presence of buffers that resist $\mathrm{pH}$ changes. In a freshwater system, the buffering is related to the dissolved inorganic carbon species: carbon dioxide $\left(\mathrm{CO}_{2}\right)$, bicarbonate ion $\left(\mathrm{HCO}_{3}^{-}\right)$, and carbonate ion $\left(\mathrm{CO}_{3}{ }^{-2}\right)$, which scavenges the hydrogen and hydroxide ions.
Alkalinity is a measure of the capacity of water to neutralize strong acid (Snoeyink and others, 1998). In natural water, this capacity is attributed to bases, such as carbonates, bicarbonates and hydroxide, as well as to species often present in low concentrations such as silicates, borates, and organic bases. Concentrations of total bicarbonate, total hardness $(\mathrm{mg} / \mathrm{L}$ as calcium carbonate), and total non-carbonate hardness ( $\mathrm{mg} / \mathrm{L}$ as calcium carbonate) were analyzed for trends.

Positive trend in total hardness $(\mathrm{mg} / \mathrm{L}$ as calcium carbonate) were detected at the Clinton River at Mount Clemens and the Grand River at Eastmanville (table 7). The rest of the study stations showed no-significant trend in alkalinity concentration.

\section{Suspended Sediments}

Suspended sediment refers to those soil particles that stay in suspension for some extended period of time as a result of turbulence in the fluid flow. These soil particles are either detached during a rainfall-runoff event, which ultimately ends up in rivers and streams, which are brought in suspension by high velocity flow in the alluvial section of the river. Suspended sediment can be transported downstream many miles; the distance is dependent on the sediment transport capacity of the flow. Suspended-sediment concentrations and loads were analyzed for all the nine study stations. The only positive trend (increasing concentrations) in suspendedsediment concentration was detected at Manistee River at Manistee. No significant trends were detected at the remaining eight stations.

Table 7. Summary statistics and trend results for $\mathrm{pH}$ and alkalinity at selected National Stream Quality Accounting Network stations in Michigan.

[USGS, U.S. Geological Survey; 04165500 (Clinton River at Mount Clemens), 04119300 (Grand River at Eastmanville), 04126520 (Manistee River at Manistee), 04057004 (Manistique River above Manistique), 04159010 (Pigeon River near Caseville), 04045500 (Tahquamenon River near Paradise); no., number; $\mathrm{mg} / \mathrm{L}$ as $\mathrm{CaCO} 3$, milligrams per liter as calcium carbonate; Max., maximum value; Min., minimum value; +, positive trend]

\begin{tabular}{|c|c|c|c|c|c|c|c|c|c|c|c|}
\hline \multirow{2}{*}{$\begin{array}{l}\text { USGS water-quality } \\
\text { station no. }\end{array}$} & \multirow{2}{*}{$\begin{array}{c}\text { Constituents and } \\
\text { units }\end{array}$} & \multirow{2}{*}{$\begin{array}{l}\text { Period of } \\
\text { record }\end{array}$} & \multirow{2}{*}{$\begin{array}{c}\text { No. of } \\
\text { observations }\end{array}$} & \multirow{2}{*}{$\begin{array}{l}\text { Mean } \\
\text { value }\end{array}$} & \multicolumn{5}{|c|}{ Percentile Values } & \multirow[b]{2}{*}{ p-value } & \multirow[b]{2}{*}{ Trend } \\
\hline & & & & & Max. & 75 & Median & 25 & Min. & & \\
\hline 04165500 & $\mathrm{pH}$ (standard units) & $1973-95$ & 141 & 8.0 & 8.4 & 8.2 & 8 & 7 & 7.2 & 0.001 & + \\
\hline 04119300 & $\mathrm{pH}$ (standard units) & $1979-94$ & 97 & 8.2 & 8.8 & 8.4 & 8.2 & 8 & 7.1 & .00027 & + \\
\hline 04126520 & $\mathrm{pH}$ (standard units) & 1973-94 & 160 & 7.9 & 8.3 & 8.1 & 8 & 7.8 & 7 & .042 & + \\
\hline 04057004 & $\mathrm{pH}$ (standard units) & $1975-86$ & 102 & 7.6 & 8.4 & 7.8 & 7 & 7.4 & 6.6 & .005 & + \\
\hline 04159010 & $\mathrm{pH}$ (standard units) & $1978-93$ & 87 & 8.0 & 8.6 & 8.2 & 8.0 & 7.8 & 7.3 & .039 & + \\
\hline 04045500 & $\mathrm{pH}$ (standard units) & $1974-93$ & 134 & 7.4 & 8.1 & 7.6 & 7.3 & 7.2 & 6.5 & .010 & + \\
\hline
\end{tabular}


Table 8. Summary statistics and trend results for suspended sediment at selected National Stream Quality Accounting Network stations in Michigan.

[USGS, U.S. Geological Survey; 04126520 (Manistee River at Manistee); no., number; Max., maximum value; Min., minimum value; mg/L, milligrams per liter; + , positive trend]

\begin{tabular}{|c|c|c|c|c|c|c|c|c|c|c|c|}
\hline \multirow{2}{*}{$\begin{array}{l}\text { USGS water-quality } \\
\text { station no. }\end{array}$} & \multirow[b]{2}{*}{ Constituents and units } & \multirow{2}{*}{$\begin{array}{l}\text { Period of } \\
\text { record }\end{array}$} & \multirow{2}{*}{$\begin{array}{c}\text { No. of } \\
\text { observations }\end{array}$} & \multirow{2}{*}{$\begin{array}{l}\text { Mean } \\
\text { value }\end{array}$} & \multicolumn{5}{|c|}{ Percentile Values } & \multirow[b]{2}{*}{ p-value } & \multirow[b]{2}{*}{ Trend } \\
\hline & & & & & Max. & 75 & Median & 25 & Min. & & \\
\hline 04126520 & Suspended Sediment (mg/L) & 1974-94 & 140 & 9 & 60 & 10 & 8 & 5 & 1 & 0.049 & + \\
\hline
\end{tabular}

\section{MAGNITUDE OF THE DETECTED TRENDS IN SURFACE-WATER QUALITY}

The magnitude of the trend was estimated by the Thiel/Sen Slope estimator, described by Smith and others (1982). These slopes, expressed as a change in constituent concentration units per year, are ranked, and the median value is chosen to indicate the magnitude of the trend. Although the calculated trend slope indicates the general relation between values near the beginning and end of the record, this slope does not represent all the data variation within the selected period of record. The actual data may change linearly, may change in steps, or may reverse during portions of the selected period. However, the Thiel/Sen slope estimator provides a means of assessing the change in concentration over time based on the trend tests (figs. 3-15).
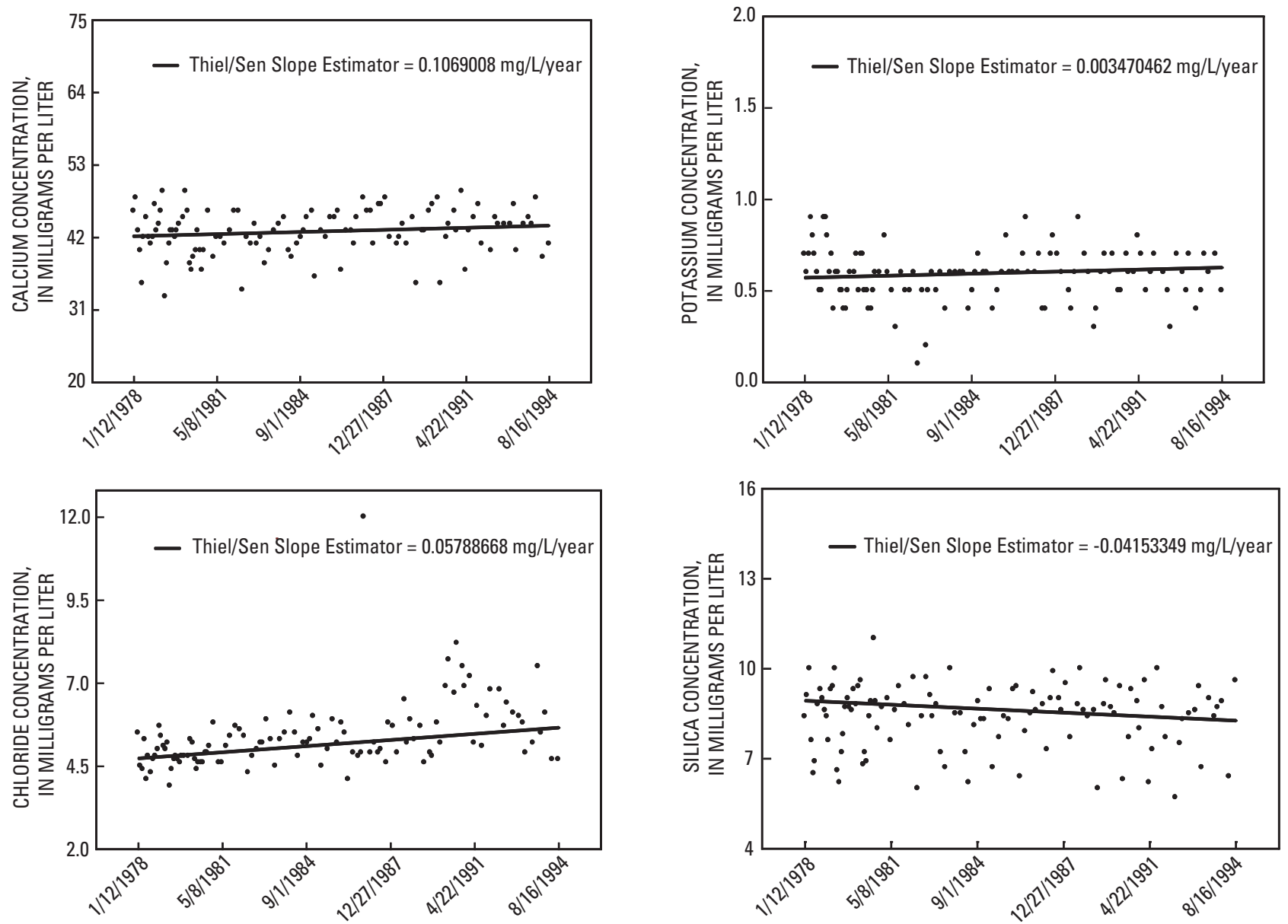

Figure 3. Significant trends detected in water-quality constituents at the Au Sable River near Au Sable (014137500), Michigan. (The Thiel / Sen Slope estimator shows changes in constituent concentrations in milligrams per liter per year (mg/L/year)). 

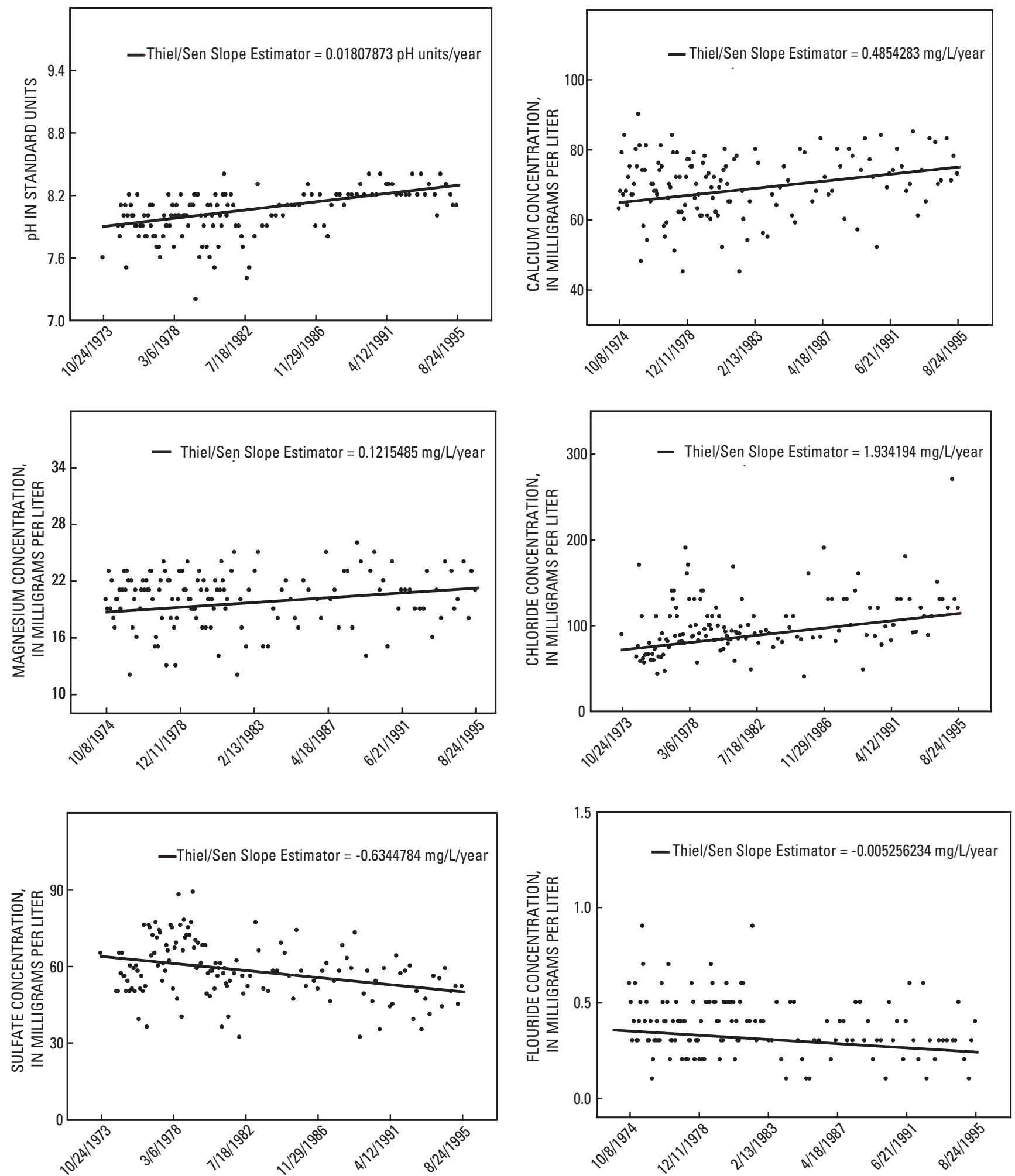

Figure 4. Significant trends detected in water-quality constituents at the Clinton River at Mount Clemens (04165500), Michigan. (The Thiel / Sen Slope estimator shows changes in constituent concentrations in milligrams per liter per year (mg/L/year)). 

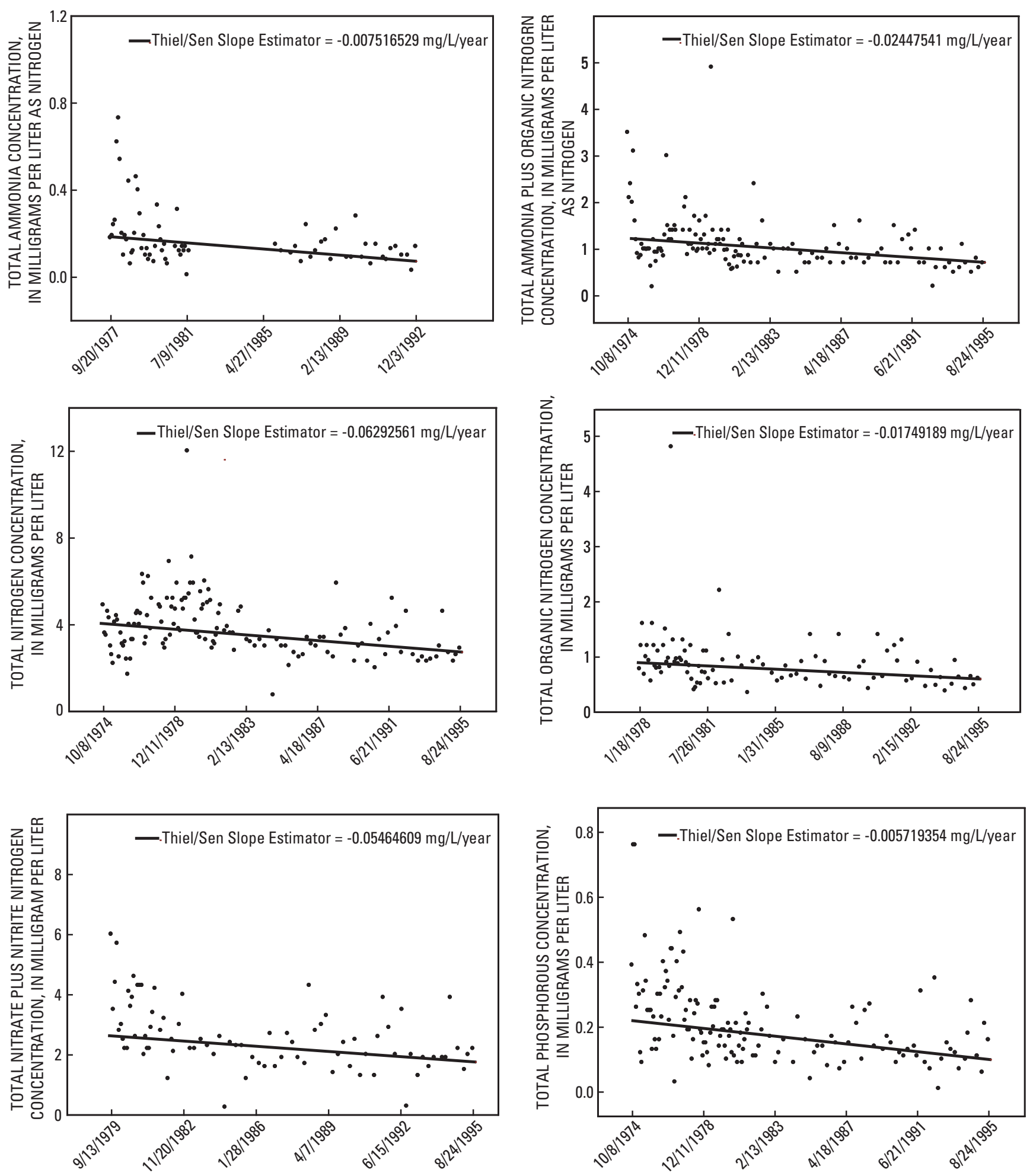

Figure 5. Significant trends detected in water-quality constituents at the Clinton River at Mount Clemens (04135500), Michigan. (The Thiel / Sen Slope estimator shows changes in constituent concentrations in milligrams per liter per year (mg/L/year)). 


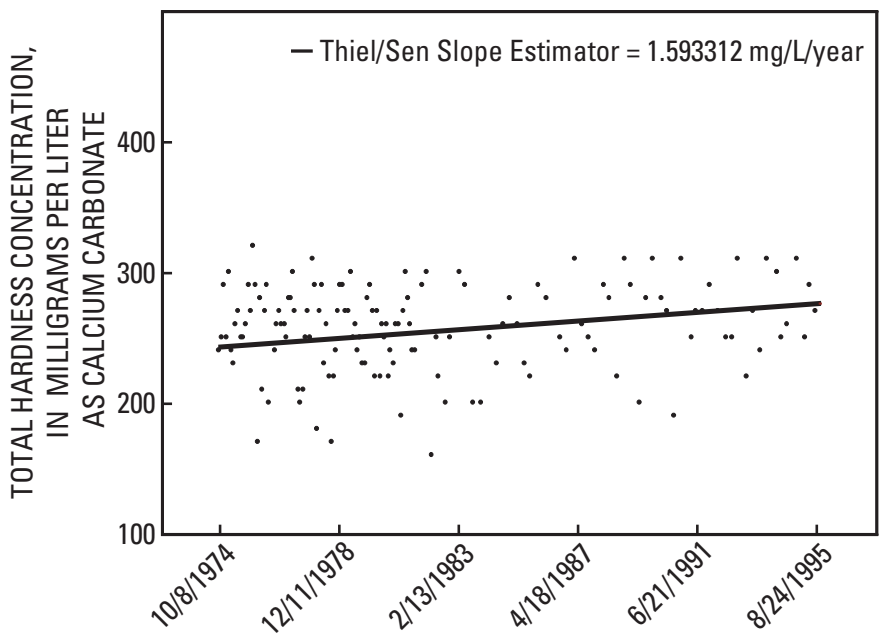

Figure 6. Significant trends detected in water-quality constituents at the Clinton River at Mount Clemens (04135500), Michigan. (The Thiel / Sen Slope estimator shows changes in constituent concentrations in milligrams per liter per year (mg/L/year)).
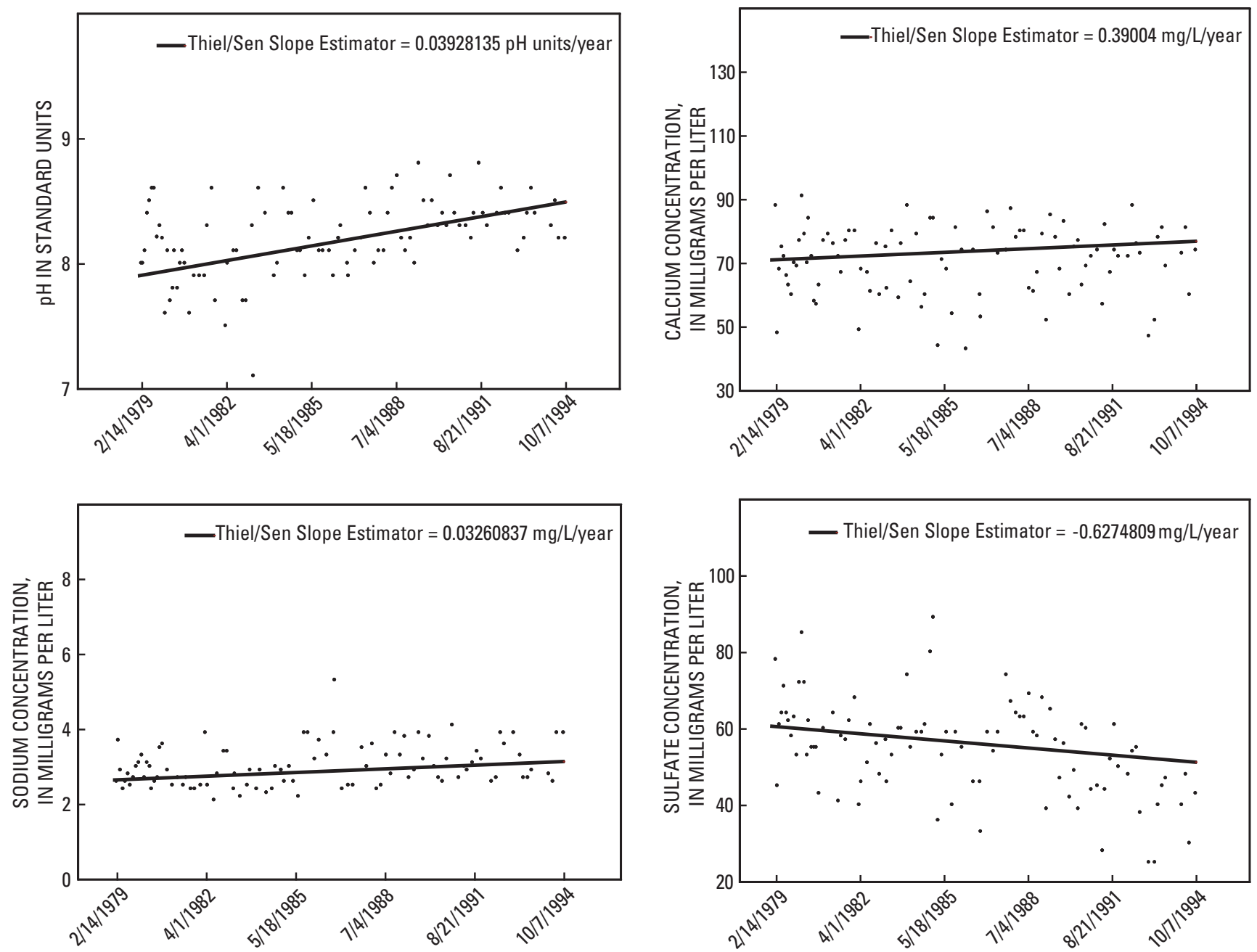

Figure 7. Significant trends detected in water-quality constituents at the Grand River at Eastmanville (04119300), Michigan. (The Thiel/ Sen Slope estimator shows changes in constituent concentrations in milligrams per liter per year (mg/L/year)). 

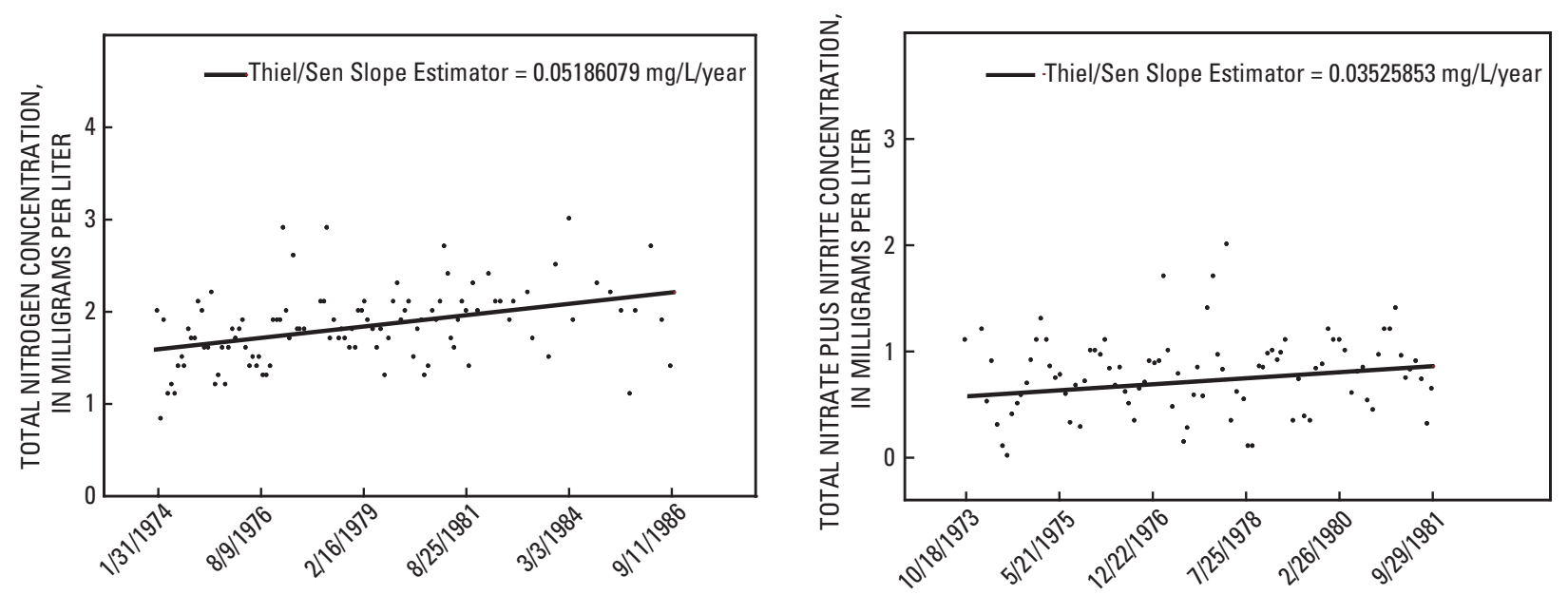

Figure 8. Significant trends detected in water-quality constituents at the Kalamazoo River near Saugatuck (04108690), Michigan. (The Thiel / Sen Slope estimator shows changes in constituent concentrations in milligrams per liter per year (mg/L/year)). 

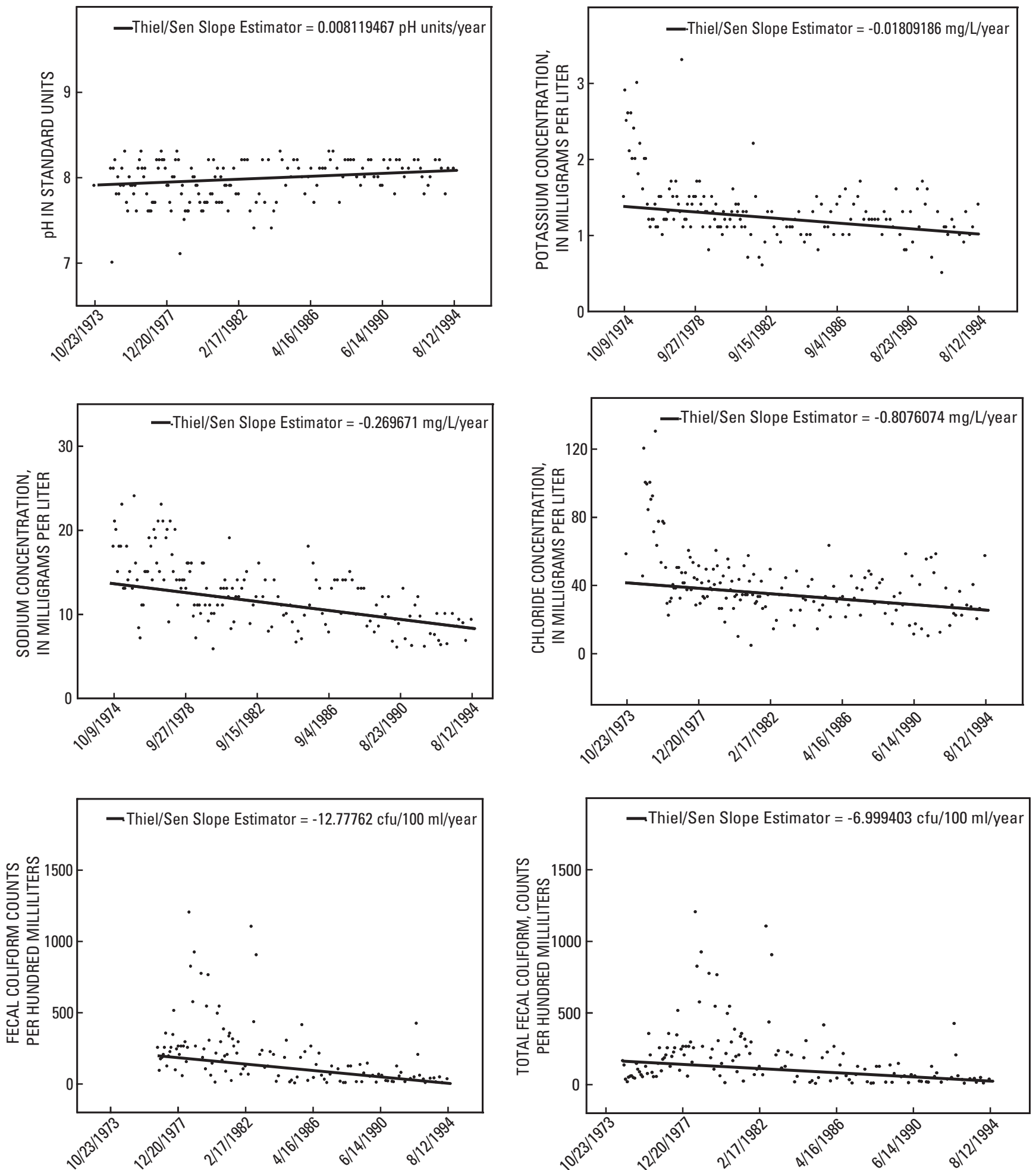

Figure 9. Significant trends detected in water-quality constituents at the Manistee River at Manistee (04126520), Michigan. (The Thiel / Sen Slope estimator shows changes in constituent concentrations in milligrams per liter per year (mg/L/year); colonies forming units per hundred milliliters of the sample per year (cfu/100ml/year)). 

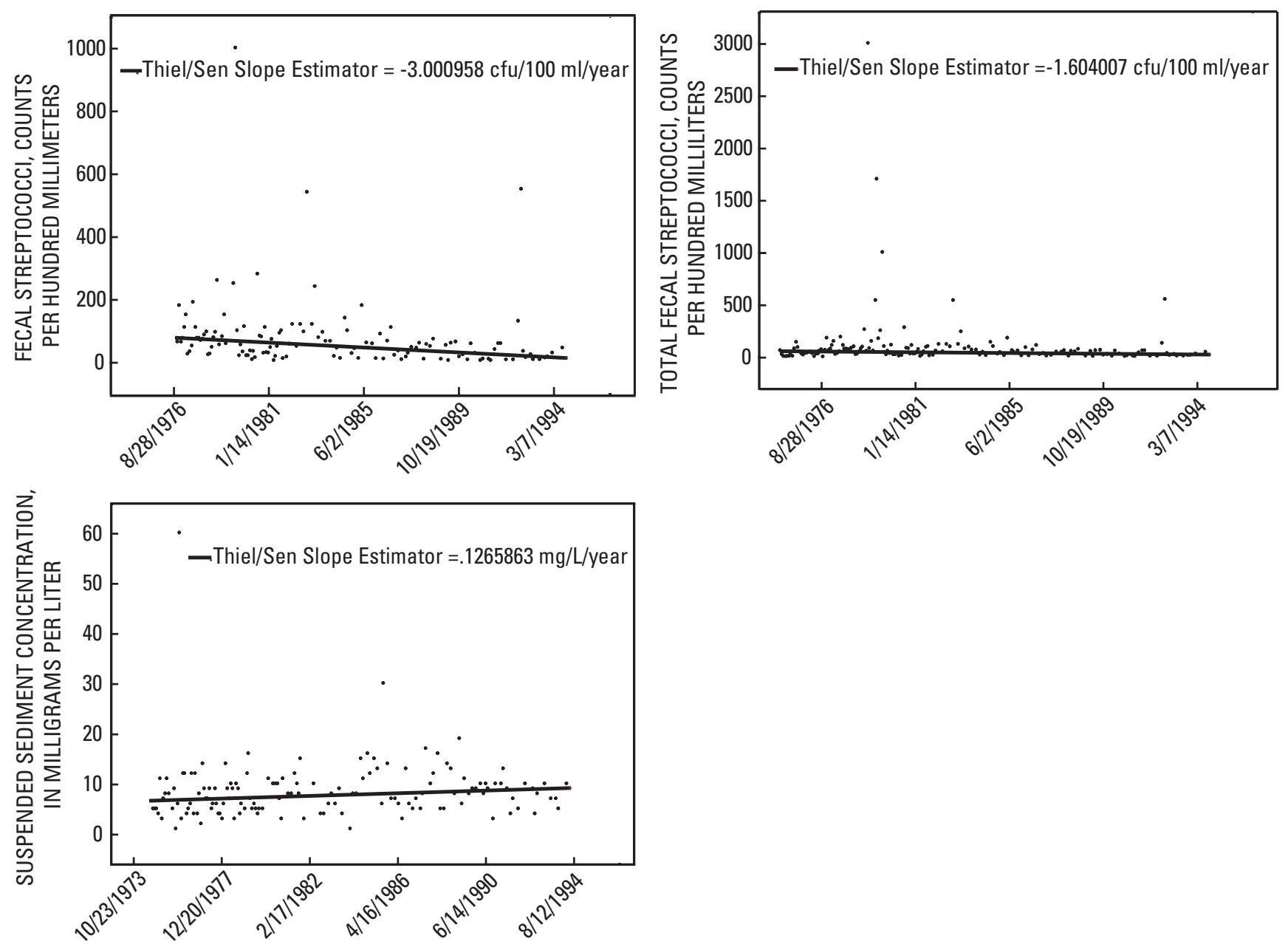

Figure 10. Significant trends detected in water-quality constituents at the Manistee River at Manistee (04126520), Michigan. (The Thiel / Sen Slope estimator shows changes in constituent concentrations in milligrams per liter per year (mg/L/year); colonies forming units per hundred milliliters of the sample per year (cfu/100ml/year)). 

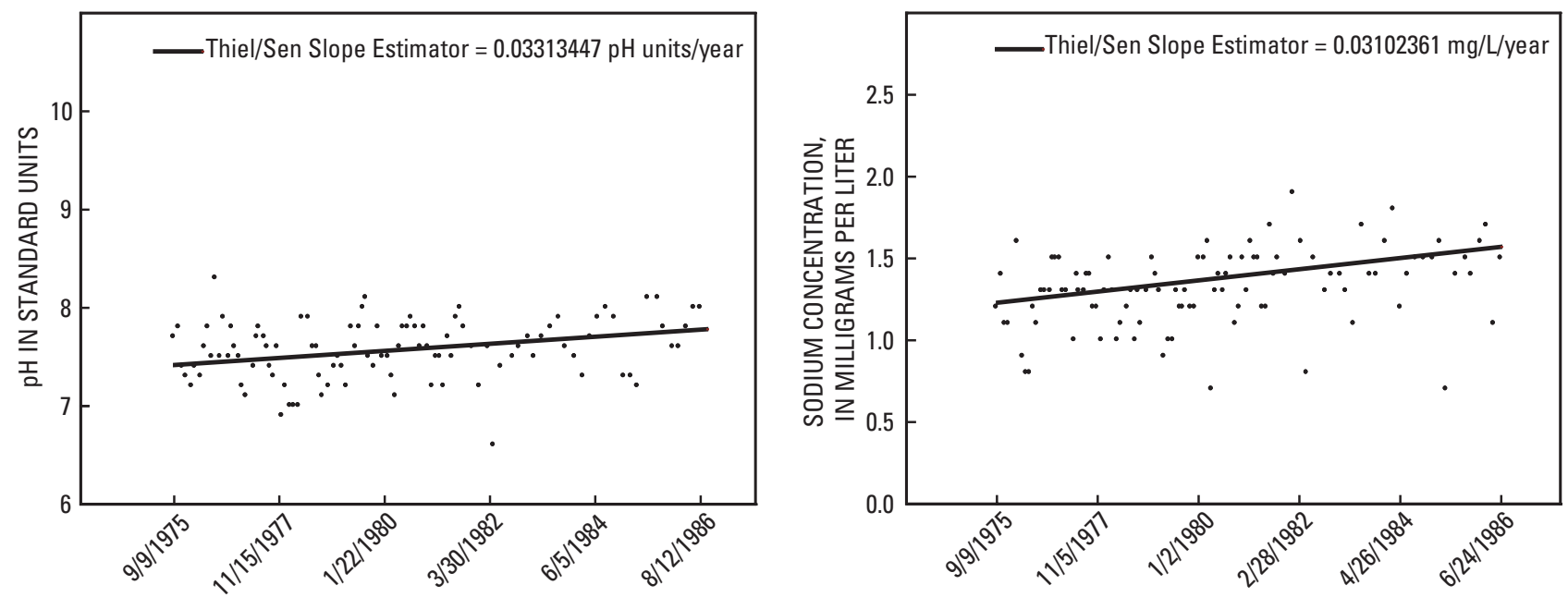

Figure 11. Significant trends detected in water-quality constituents at the Manistique River above Manistique (04157004), Michigan. (The Thiel / Sen Slope estimator shows changes in constituent concentrations in milligrams per liter per year (mg/L/year)). 

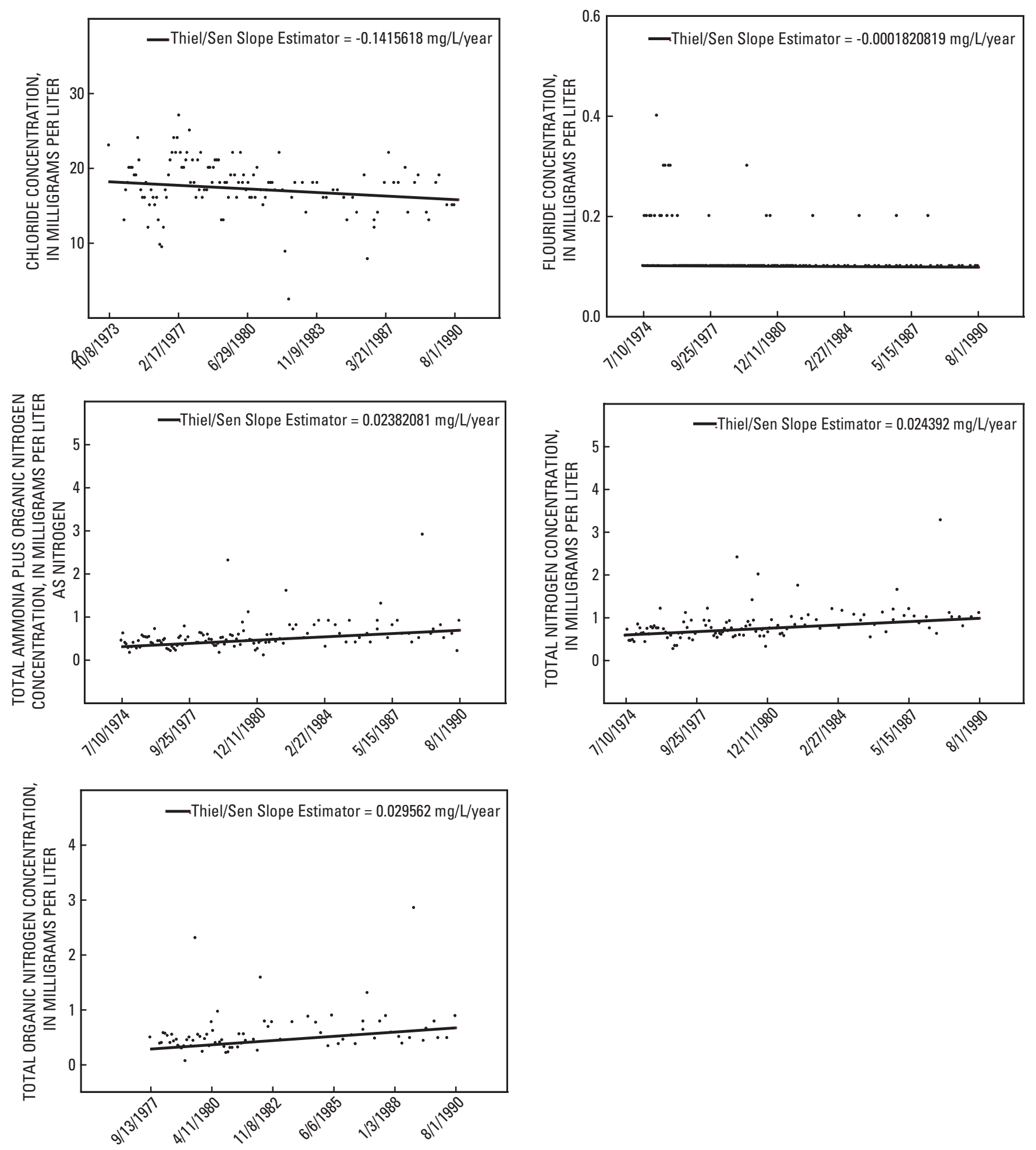

Figure 12. Significant trends detected in water-quality constituents at the Muskegon River near Bridgeton (04122030), Michigan. (The Thiel / Sen Slope estimator shows changes in constituent concentrations in milligrams per liter per year (mg/L/year)). 

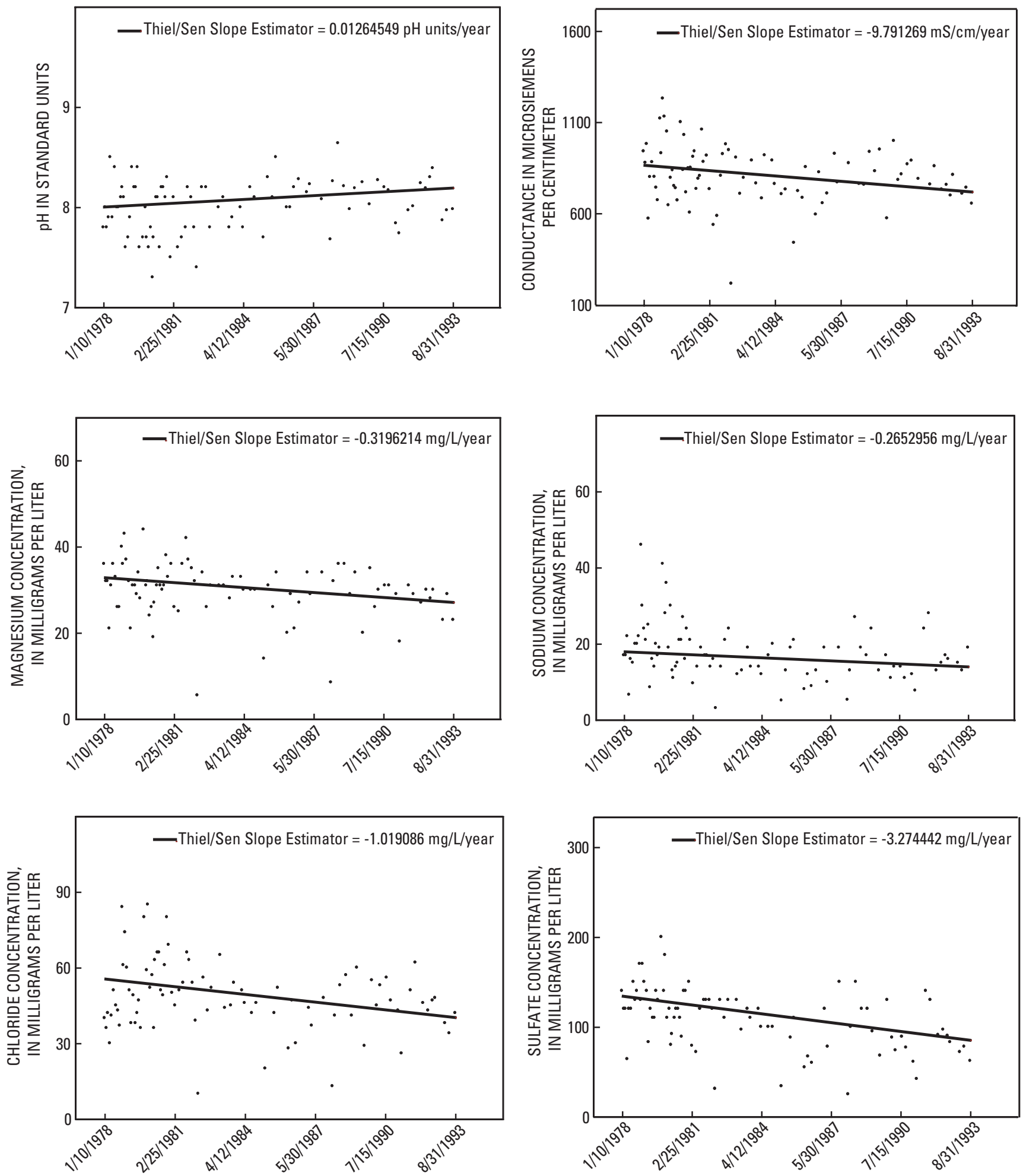

Figure 13. Significant trends detected in water-quality constituents at the Pigeon River near Caseville (04159010), Michigan. (The Thiel / Sen Slope estimator shows changes in constituent concentrations in milligrams per liter per year (mg/L/year); microsiemens per centimeter per year $(\mu \mathrm{S} / \mathrm{cm} / \mathrm{year}))$. 

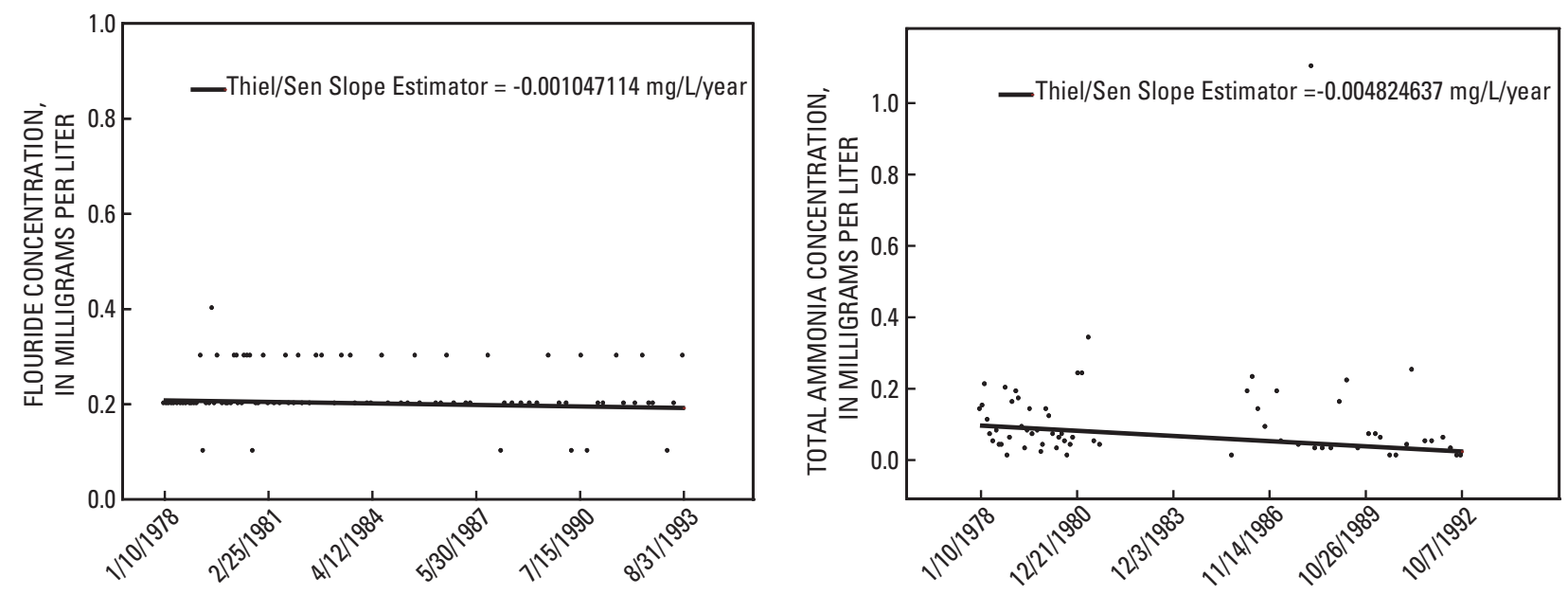

Figure 14. Significant trends detected in water-quality constituents at the Pigeon River near Caseville (04159010), Michigan. (The Thiel / Sen Slope estimator shows changes in constituent concentrations in milligrams per liter per year (mg/L/year)). 

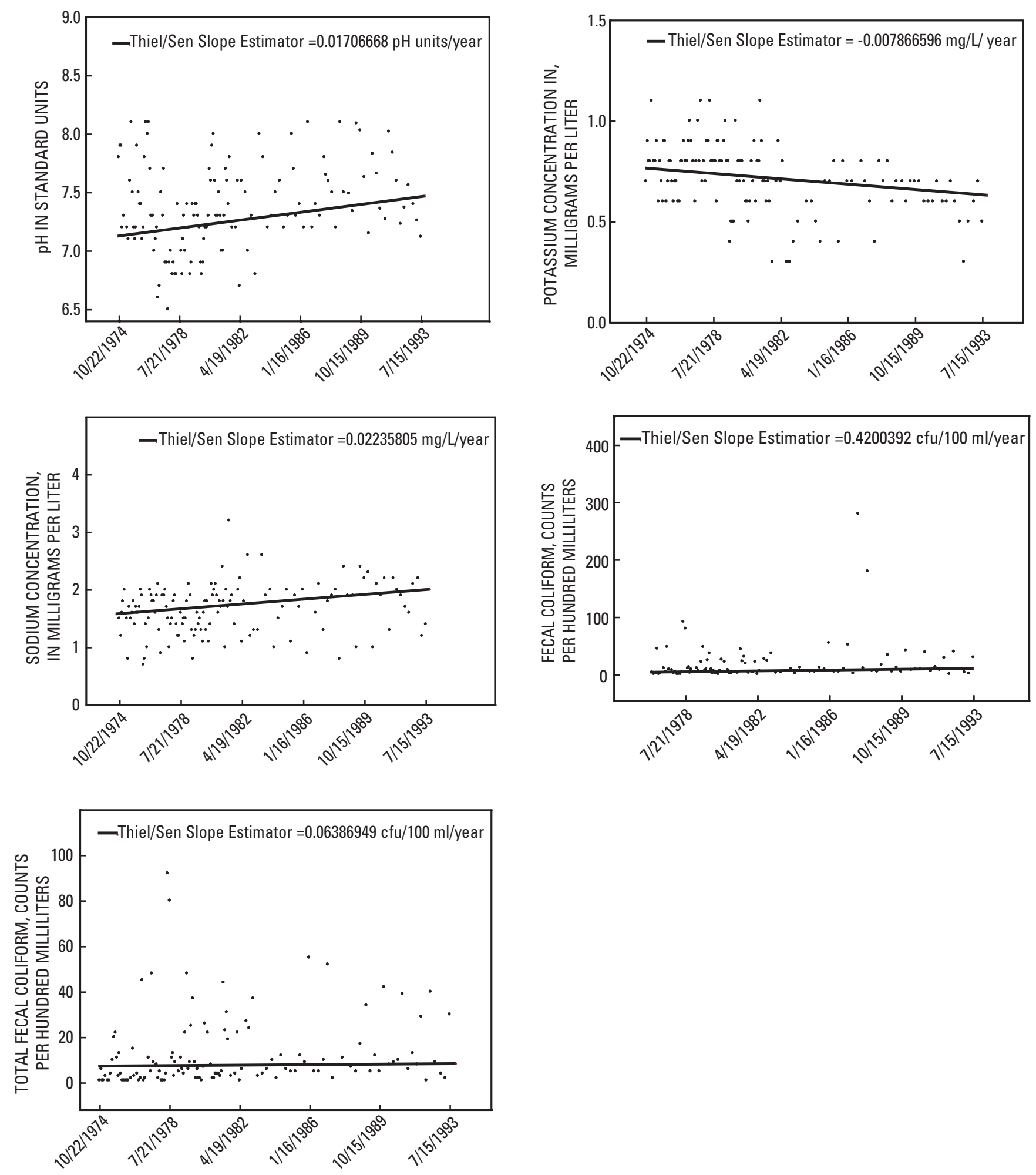

Figure 15. Significant trends detected in water-quality constituents at the Tahquamenon River near Paradise (04045500), Michigan. (The Thiel / Sen Slope estimator shows changes in constituent concentrations in milligrams per liter per year (mg/L/year); colonies forming units per hundred milliliters of the sample per year (cfu/100ml/year)). 


\section{SUMMARY AND CONCLUSIONS}

The U.S. Geological Survey (USGS) National Stream Quality Accounting Network (NASQAN) program operated 34 surface-water quality stations in the State of Michigan from 1973 to 1995. Sampling frequencies varied from monthly at the beginning of the program to between four and five samples annually in the early 1990's. The program was eventually discontinued in 1995. Water-quality sampling was reinstated through a cooperative effort known as the Clean Michigan Initiative (CMI) with the Michigan Department of Environmental Quality (MDEQ). To demonstrate the value of long-term, water-quality monitoring, the USGS, in cooperation with the MDEQ, initiated this study to evaluate the NASQAN data for use in identifying trends in water-quality constituents for nine selected stations. The results from this study would help the MDEQ in assessing the effectiveness of water-pollution control efforts since the initiation of the Clean Water Act in 1972.

For this study, a total of 9 NASQAN stations were selected and approximately 28 constituents were evaluated at each station. Station selection was based on data availability, land-use characteristics, and station priority for the MDEQ Water Chemistry Monitoring Project (WCMP). The trend analyses were completed using the ESTREND statistical software package. ESTREND is a statistical program used mainly for the investigations of trends in water-quality data. Changing seasons, waterquality records with missing values, censored ("lessthan") data, and flow-adjusted constituent concentration are accounted for in the trend tests. The water-quality data chosen for the trend tests had: (1) at least a 5-year period of record, (2) less than 5 percent of the observations censored at a single reporting limit, and (4) 40 percent of the values within the beginning one-fifth and ending one-fifth of the selected period. Sampling parameters that did not meet these criteria were not included for trend-test analyses. In this study, a negative trend indicates, a decrease in concentration of a particular constituent, which generally means an improvement in water quality; whereas a positive trend indicates an increase in concentration of a particular constituent and possible degradation of water quality. Significant trends detected during the study represent constituents with flow-adjusted concentrations.

Results of the trend analyses showed an overall improvement in water quality at the Clinton River at Mount Clemens, Manistee River at Manistee, and Pigeon River near Caseville stations. The detected trends for these stations showed decreases in concentration of various constituents including nitrogen compounds, specific conductance, sulfate, fecal coliform bacteria, and fecal streptococci bacteria. The station with the most signifi- cant improvement in bacterial contamination was the Manistee River at Manistee. Significant negative trends were detected in fecal coliform, total fecal coliform, fecal streptococci, and total fecal streptococci at this station. Similarly, the Clinton River at Mount Clemens station had significant decreases in nitrogen compound concentrations. At this station, negative trends in concentrations were detected in total ammonia, total ammonia plus organic nitrogen, total organic nitrogen, total nitrite plus nitrate ( $\mathrm{mg} / \mathrm{L}$ as nitrogen), and total nitrogen. These negative trends may indicate an overall improvement in agricultural practices, municipal and industrial wastewater-treatment processes, and effective regulations.

The Pigeon River near Caseville station indicated water-quality improvements (negative trends) in a variety of constituents including conductance, chloride, sodium, sulfate, and total ammonia.

Phosphorus data for most of the selected stations have 20 percent of the concentrations less than the analytical detection limit with more than one censoring level. This condition is a limiting factor for detecting trends in surface-water quality constituents using the uncensored Seasonal Kendall test. The only station with a significant negative trend in total phosphorus concentration is the Clinton River at Mount Clemens. However, scatter-plot analyses of phosphorus data indicate decreasing phosphorus concentrations at most of the study stations.

Positive trends in concentrations of nitrogen compounds were detected at the Kalamazoo River near Saugatuck and Muskegon River near Bridgeton. Positive trends in both fecal coliform and total fecal coliform were detected at the Tahquamenon River near Paradise station. Various different point and nonpoint sources could produce such increases, but most commonly the increase in concentrations of nitrogen compounds and fecal coliform bacteria are related to changes in agricultural practices or sewage-plant discharges.

$\mathrm{pH}$ levels increased at six out of nine stations on all the major rivers. No negative trends (decreasing concentration) in $\mathrm{pH}$ levels were detected at any of the stations. The possible causes of $\mathrm{pH}$ increase are difficult to determine. $\mathrm{pH}$ changes may be affected by many factors, such as temperature; by reactions of dissolved carbon dioxide with water; by reactions in which solid materials are dissolved, precipitated, or oxidized; and by the photosynthetic activity of aquatic organisms, which take up dissolved carbon dioxide during the day and release it at night. Increases in $\mathrm{pH}$ may be related to decreasing concentration of ammonia, or changes in regulatory requirements concerning the neutralization of municipal and industrial wastewater.

In addition to $\mathrm{pH}$, numerous trends were detected in chloride and sodium concentrations on all the major rivers. A total of three positive and two negative trends 
were detected in sodium concentration, and three negative and two positive trends were detected in chloride concentrations. Anthropogenic sources of chloride commonly include deicing salt, sewage effluents, industrial wastes, and oil fields.

Trends in concentrations of other major ions, such as calcium, magnesium, sulfate, fluoride and potassium, were detected at stations throughout Michigan. Negative trends were detected only in sulfate and fluoride concentrations; on the contrary, only positive trends were detected in calcium concentrations. For other major ions, such as magnesium and potassium, both positive and negative trends were detected.

It is important to note that the period of record for this study encompasses a period of improvement and sophistication in sampling methods and analytical techniques. Improvements in analytical methods for most constituents may be related, in part, to measurement bias, which is difficult to take into account in waterquality trend tests. This difficulty arises because of the relative effects and the magnitude change in constituent concentrations in most cases is difficult to determine. Therefore, it can be assumed that in this study the detected trends in some water-quality constituents may be biased because of the improved analytical techniques and sampling methods.

\section{ACKNOWLEDGMENTS}

The authors thank Christina Aiello, Surface Water Assessment Section, Water Bureau, Michigan Department of Environmental Quality (MDEQ) for her review of this report. In addition, the authors express their appreciation to the USGS personnel who participated in the collection and analysis of NASQAN and CMI data and in the preparation and review of this report. Richard Jodoin provided GIS support, Sharon Baltusis helped in the preparation of the figures, and Denis Healy provided information regarding statistical techniques and methods for analyses of water-quality data.

\section{REFERENCES CITED}

Alexander, R.B., Ludtke, A.S., Fitzgerald, K.K., and Schertz, T.L., 1996, Data from selected U.S. Geological Survey national stream water-quality monitoring networks (WQN) on CD-ROM: U.S. Geological Survey Open-File Report 96-337.
Alexander, R.B., Slack, J.R., Ludtke, A.S., Fitzgerald, K.K., and Schertz, T.L., 2005, Data from selected U.S. Geological Survey national stream water-quality monitoring networks (WQN): USGS Digital Data Series DDS-37, accessed June 1, 2005, at URL http://water.usgs.gov/pubs/dds/wqn96cd/ index.htm

Clinton River Watershed Public Advisory Council and Michigan Department of Environmental Quality, 1997, Clinton River Watershed Remedial and Preventive Action Plan, 1997 Update and Progress Report.

Digest of Federal Resource Laws of Interest to the U.S. Fish and Wildlife Service, 1972, accessed May 31, 2005, at URL http://laws.fws.gov/lawsdigest/fwatrpo.html.

Environmental Protection Agency, 1986, Ambient Water Quality Criteria for Bacteria-1986, EPA/440/5-84-002., Office of Water Regulations and Standards, USEPA, Washington, D.C.

Ficke, J.F., and Hawkinson, R.O., 1975, The National Stream Quality Accounting Network (NASQAN)--some questions and answers: U.S. Geological Survey Circular 719, 23 p.

Hirsch, R.M., Slack, J.R., and Smith, R.A., 1981, Techniques of trend analysis for monthly water-quality data: Water Resources Research, v. 20, no. 1, p. 727-732.

U.S. Environmental Protection Agency, 2005a, National Priorities List, accessed June 1, 2005, at URL http://www.epa. gov/superfund/sites/npl/

Schertz, T.L., Alexander, R.B., and Ohe, D.J., 1991, The computer program Estimate Trend (ESTREND), a system of detection of trends in water quality data: U.S. Geological Survey Water-Resources Investigations Report 91-4040, 63 p.

Schertz, T.L., and Hirsch, R.M., 1985, Trend analysis of weekly acid rain data: U.S. Geological Survey WaterResources Investigations Report 85-4211, 64 p.

Smith, R.A., Hirsch, R.M., and Slack, J.R., 1982, A study of trends in total phosphorus measurements at NASQAN stations: U.S. Geological Survey Water-Supply Paper 2190, 33 p.

Snoeyink, V.L., and Jenkins, D., 1998, Water chemistry: John Wiley and Sons, Inc. New York, 463 p.

U.S. Environmental Protection Agency, 2005b, Sulfate in Drinking Water: U.S. Groundwater and Drinking Water Safety Program, accessed June 1, 2005, at URL, http:// www.epa.gov/safewater/sulfate.html 



\section{Appendix A.}

Summary statistics and Trend-Test Results for selected National Stream Quality Accounting Network (NASQAN) stations in Michigan 
Appendix A-1. Summary statistics and trend test results of water-quality data for the Au Sable River near Au Sable (04137500), Mich.

[USGS, U.S. Geological Survey; Max., maximum value; Min., minimum value; ${ }^{\circ} \mathrm{C}$, degrees Celsius; NTU, nephelometric turbidity units; mg/L, milligrams per liter; $\mu \mathrm{S} / \mathrm{cm}$, microsiemens per centimeter; cfu/100 ml, colony forming units per hundred milliliters of the sample ; "a", less than 40-percent of the data in the ending one-fifth of the data set; insufficient data, does not meet the criteria for trend test because of limitations in the number of data points or period of record; --, no data]

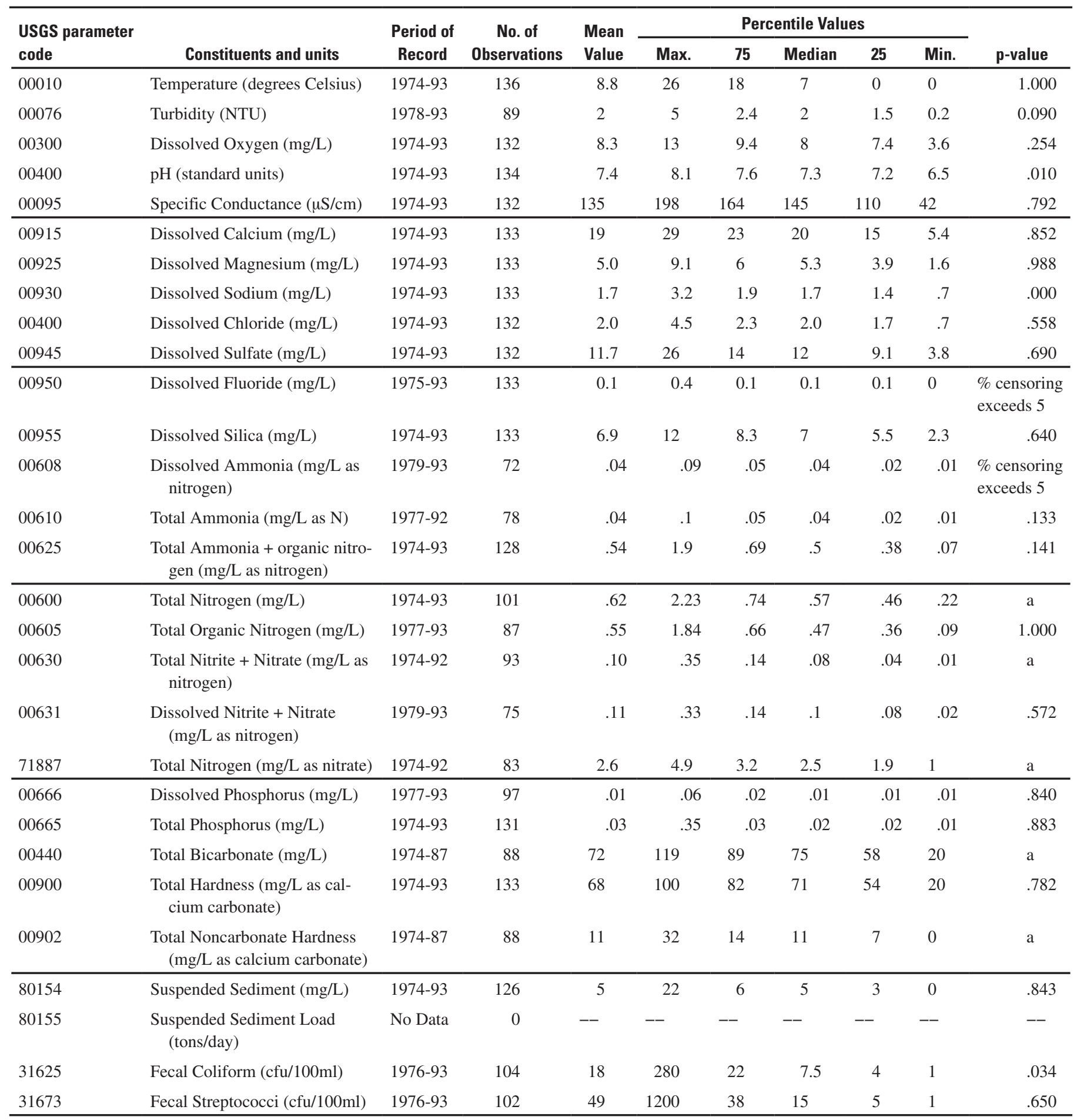


Appendix A-2. Station 04165500 Clinton River at Mt. Clemens, Mich.

[No., number; Max., maximum value; Min., minimum value; C, Celsius; NTU, nephelometric turbidity units; mg/L, milligrams per liter; $\mu \mathrm{S} / \mathrm{cm}$, mirosiemens per centimeter; "a", less than 40-percent of the data in the ending one-fifth of the data set; cfu, colony forming units]

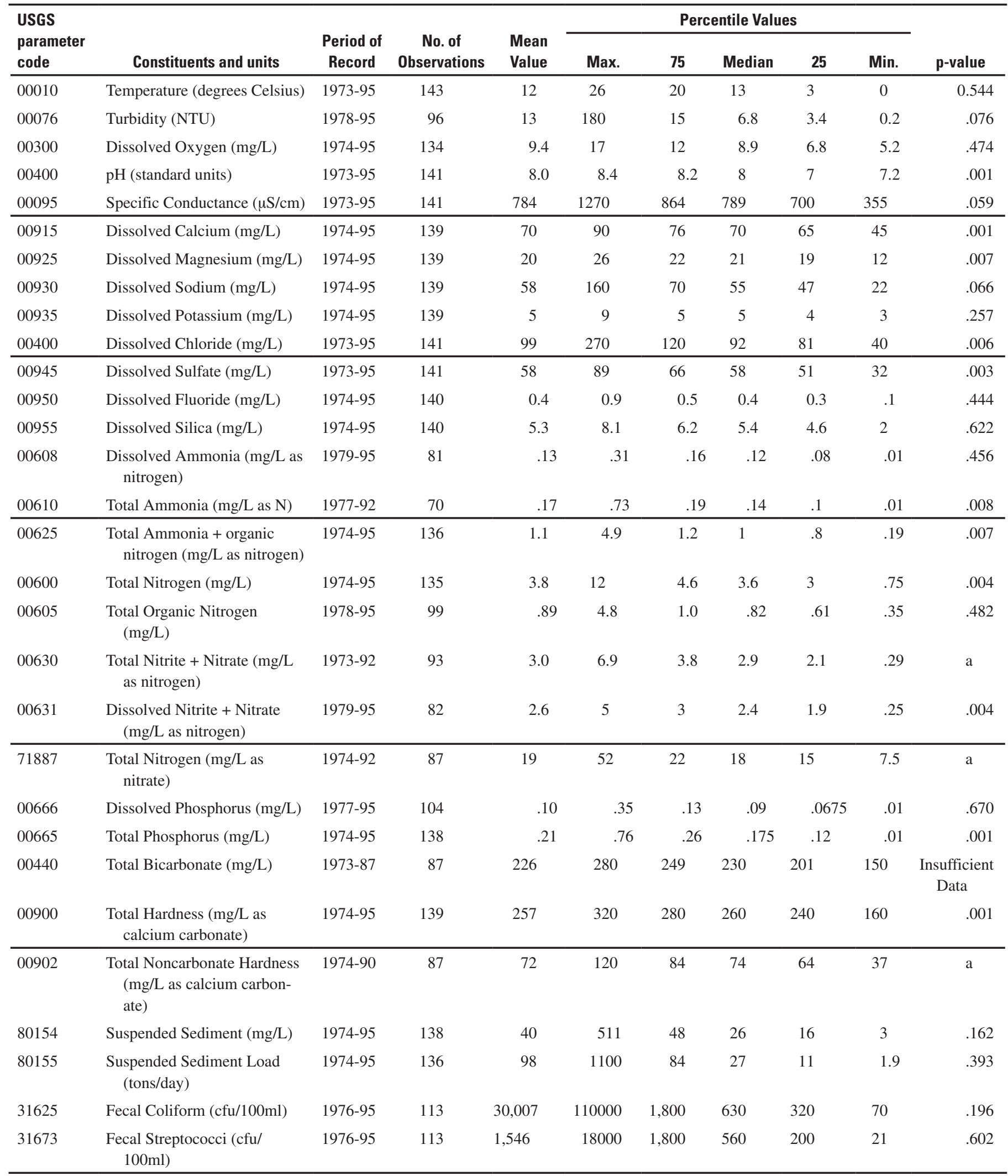


Appendix A-3. Station 04119300 Grand River near Eastmanville, Mich.

[No., number; Max., maximum value; Min., minimum value; C, Celsius; NTU, nephelometric turbidity units; mg/L, milligrams per liter; $\mu \mathrm{S} / \mathrm{cm}$, mirosiemens per centimeter; cfu, colony forming units; --, no data]

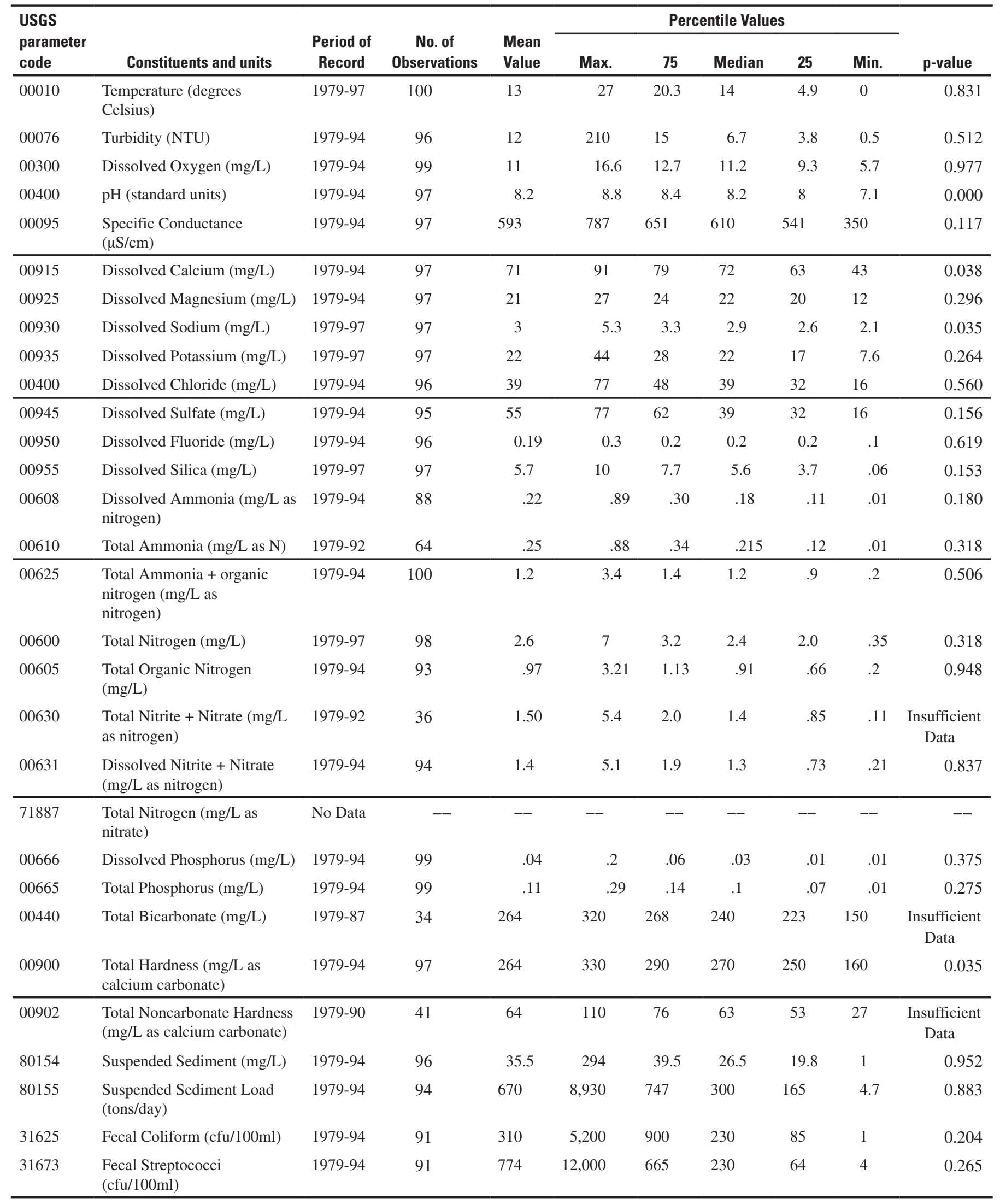


Appendix A-4. Station 04108690 Kalamazoo River at Saugatuck, Mich.

[No., number; Max., maximum value; Min., minimum value; C, Celsius; NTU, nephelometric turbidity units; mg/L, milligrams per liter; $\mu$ S/cm, mirosiemens per centimeter; "a", less than 40-percent of the data in the ending one-fifth of the data set; cfu, colony forming units]

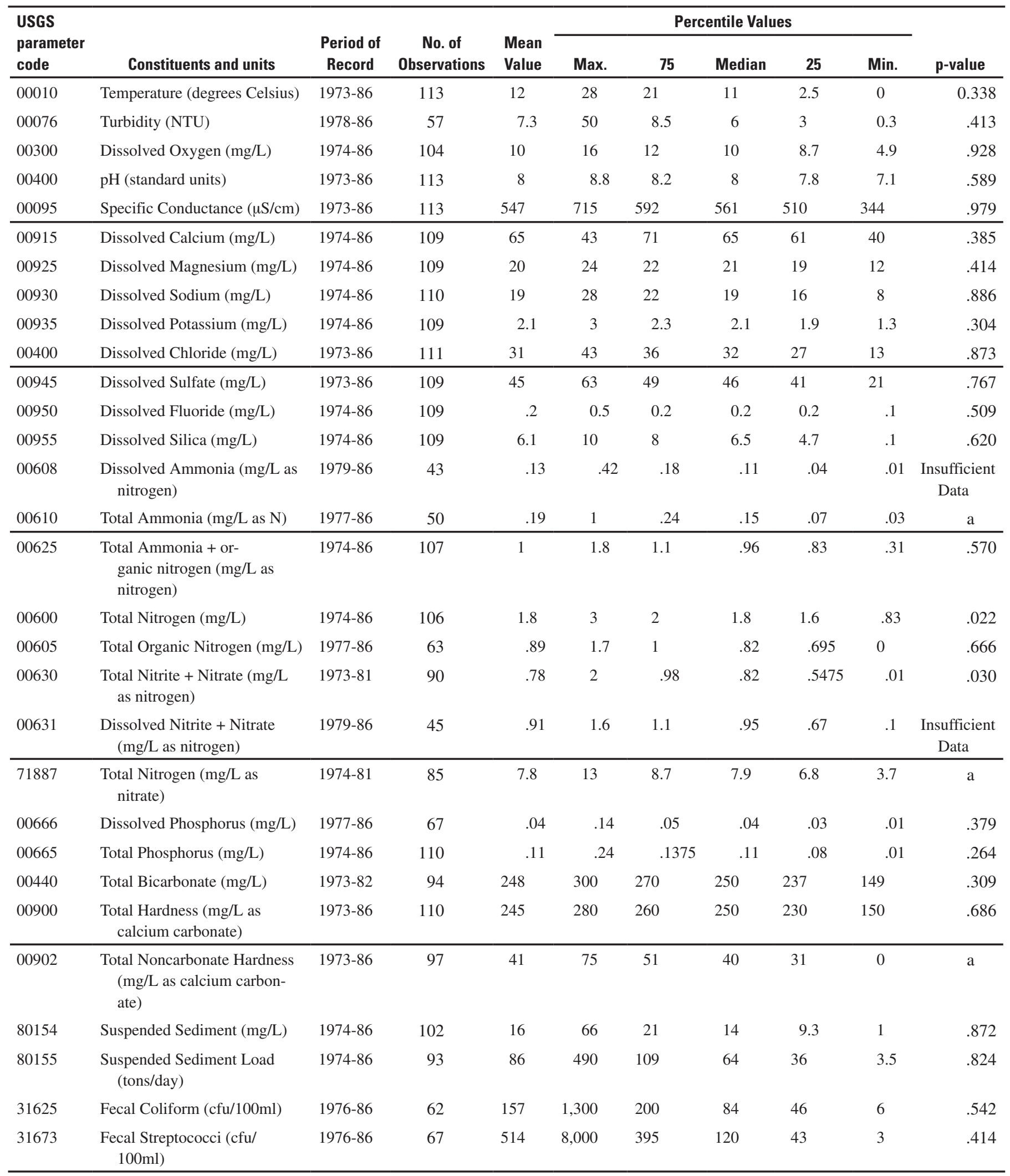


Appendix A-5. Station 04126520 Manistee River at Mansitee, Mich.

[No., number; Max., maximum value; Min., minimum value; C, Celsius; NTU, nephelometric turbidity units; mg/L, milligrams per liter; $\mu$ S/cm, mirosiemens per centimeter; "a", less than 40-percent of the data in the ending one-fifth of the data set; cfu, colony forming units]

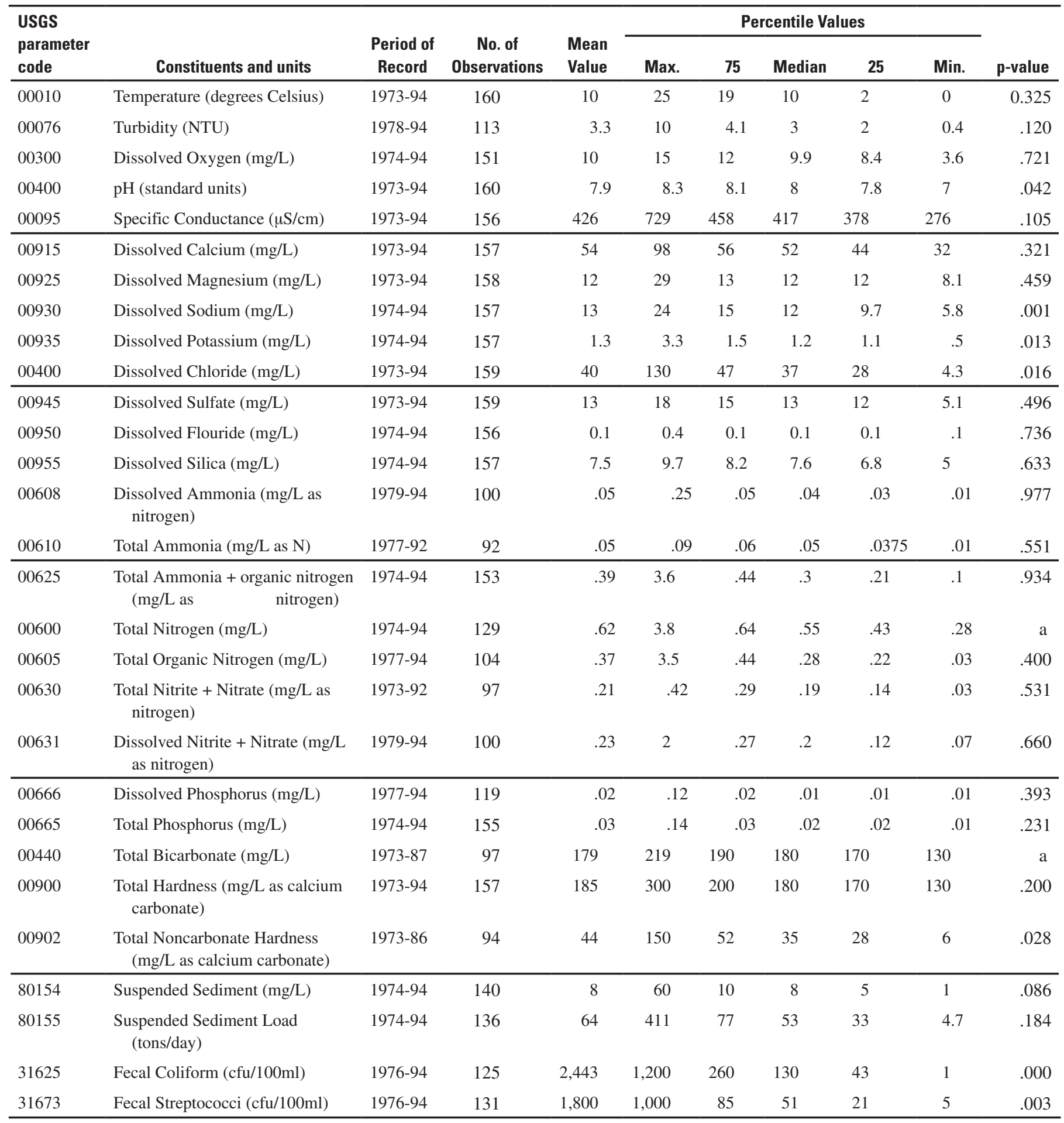


Appendix A-6. Station 04057004 Manistique River above Manistique, Mich.

[No., number; Max., maximum value; Min., minimum value; C, Celsius; NTU, nephelometric turbidity units; mg/L, milligrams per liter; $\mu$ S/cm, mirosiemens per centimeter; "a", less than 40-percent of the data in the ending one-fifth of the data set; cfu, colony forming units]

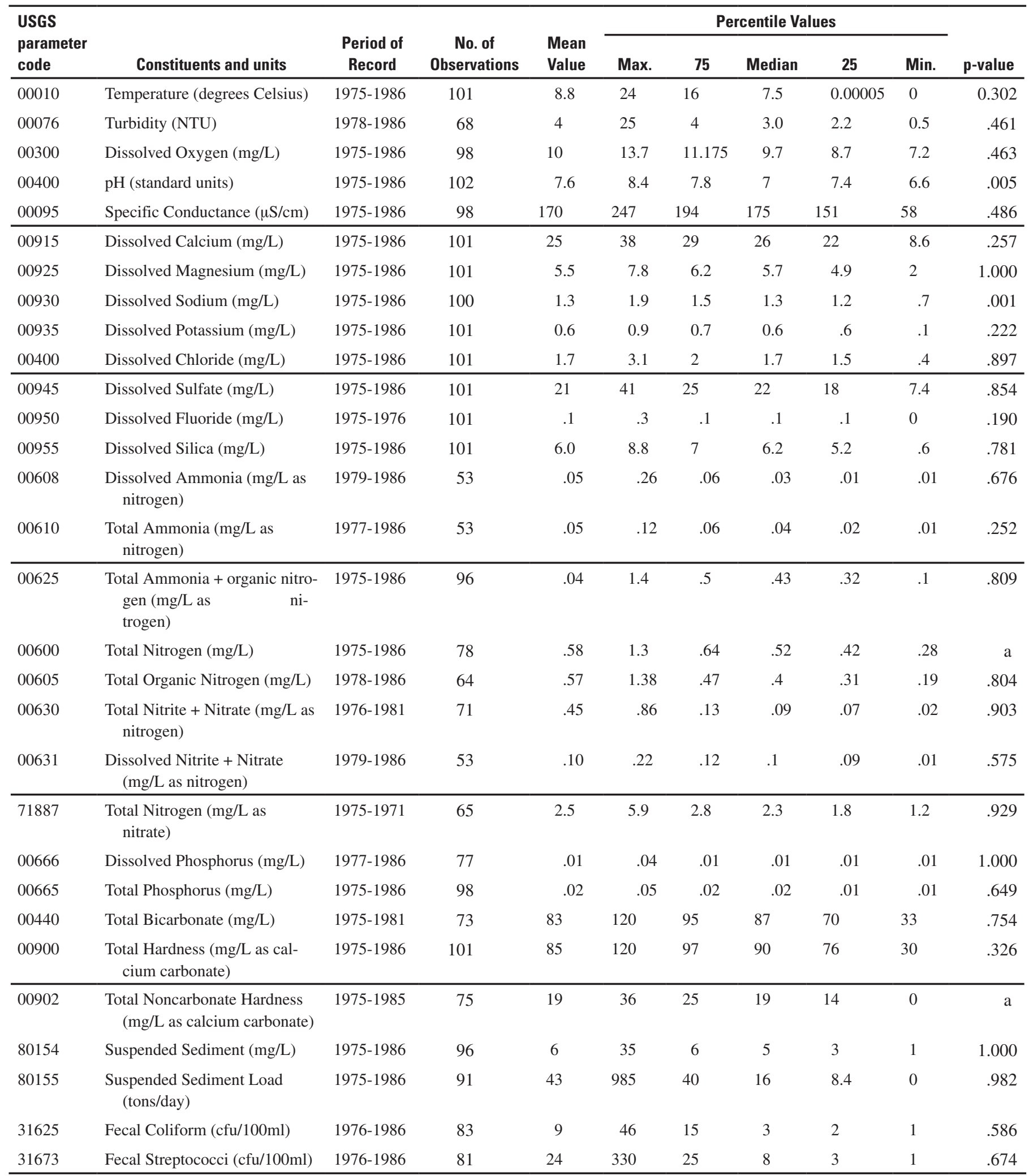


Appendix A-7. Station 04122030 Muskegon River near Bridgeton, Mich.

[No., number; Max., maximum value; Min., minimum value; C, Celsius; NTU, nephelometric turbidity units; mg/L, milligrams per liter; $\mu$ S/cm, mirosiemens per centimeter; "a", less than 40-percent of the data in the ending one-fifth of the data set; cfu, colony forming units]

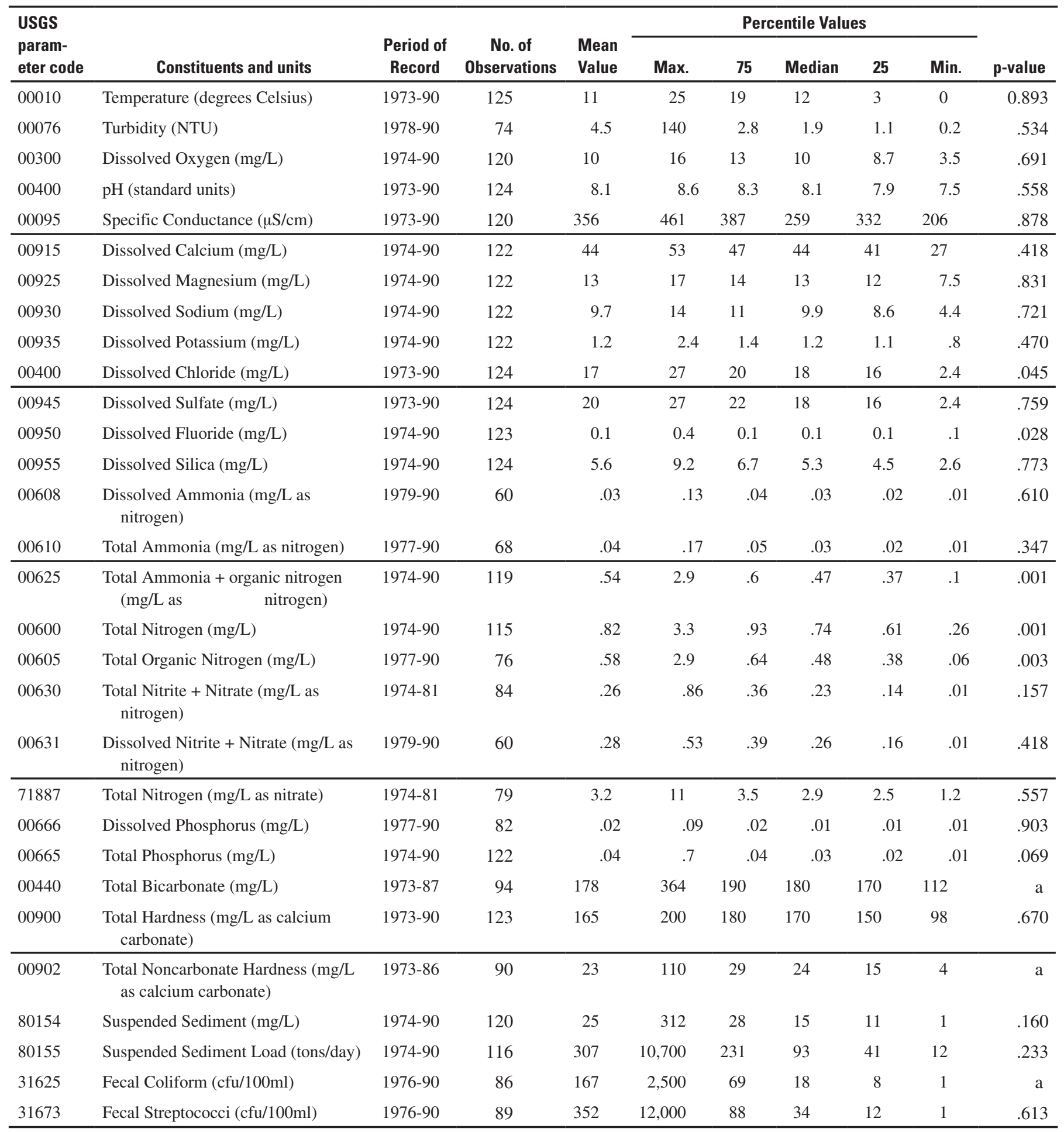


Appendix A-8. Station 04159010 Pigeon River near Pigeon, Mich.

[No., number; Max., maximum value; Min., minimum value; C, Celsius; NTU, nephelometric turbidity units; mg/L, milligrams per liter; $\mu \mathrm{S} / \mathrm{cm}$, mirosiemens per centimeter; "a", less than 40-percent of the data in the ending one-fifth of the data set; cfu, colony forming units]

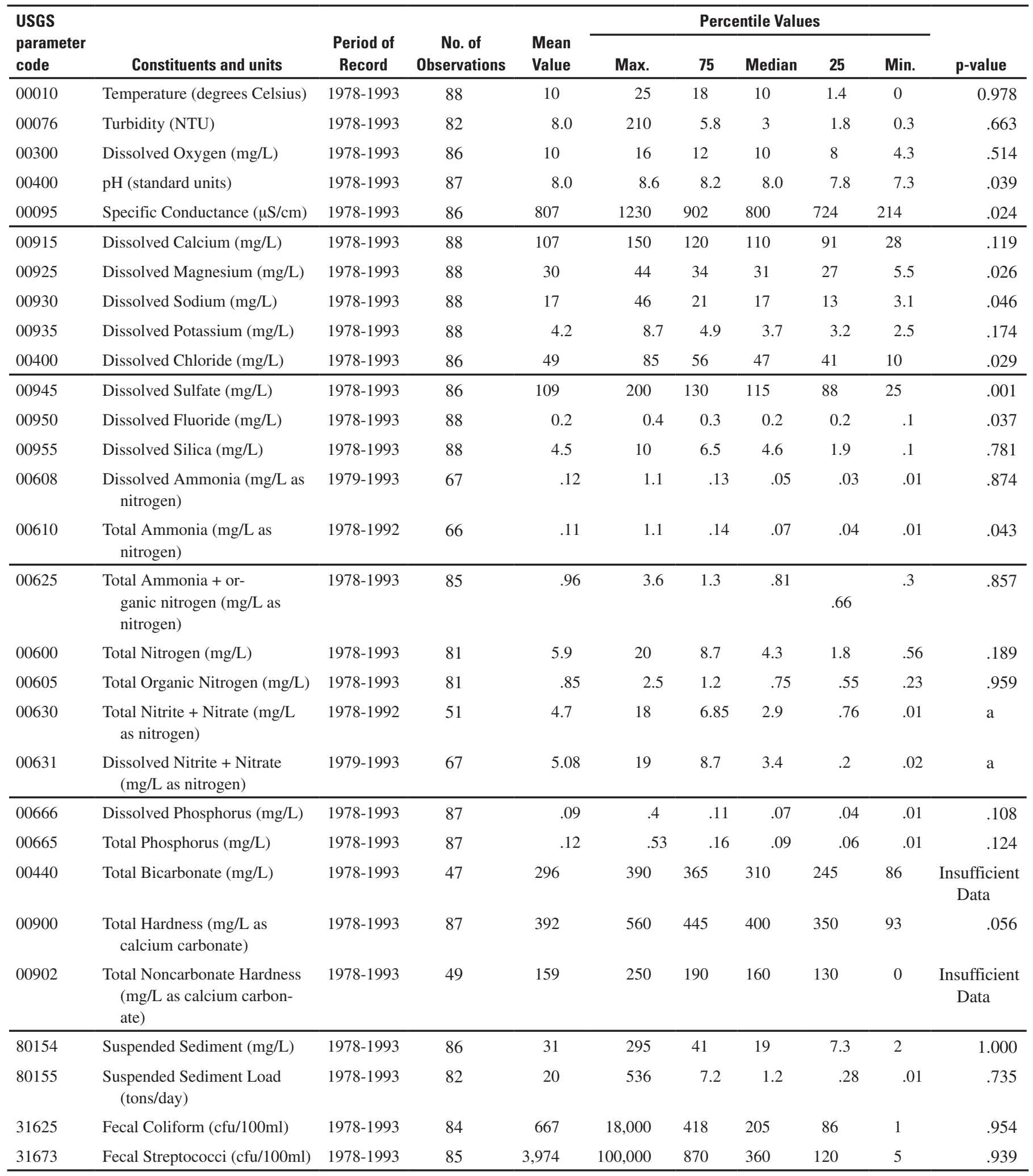


Appendix A-9. Station 04045500 Tahquamenon River near Paradise, Mich.

[No., number; Max., maximum value; Min., minimum value; C, Celsius; NTU, nephelometric turbidity units; mg/L, milligrams per liter; $\mu \mathrm{S} / \mathrm{cm}$, mirosiemens per centimeter; "a", less than 40-percent of the data in the ending one-fifth of the data set; cfu, colony forming units; --, no data]

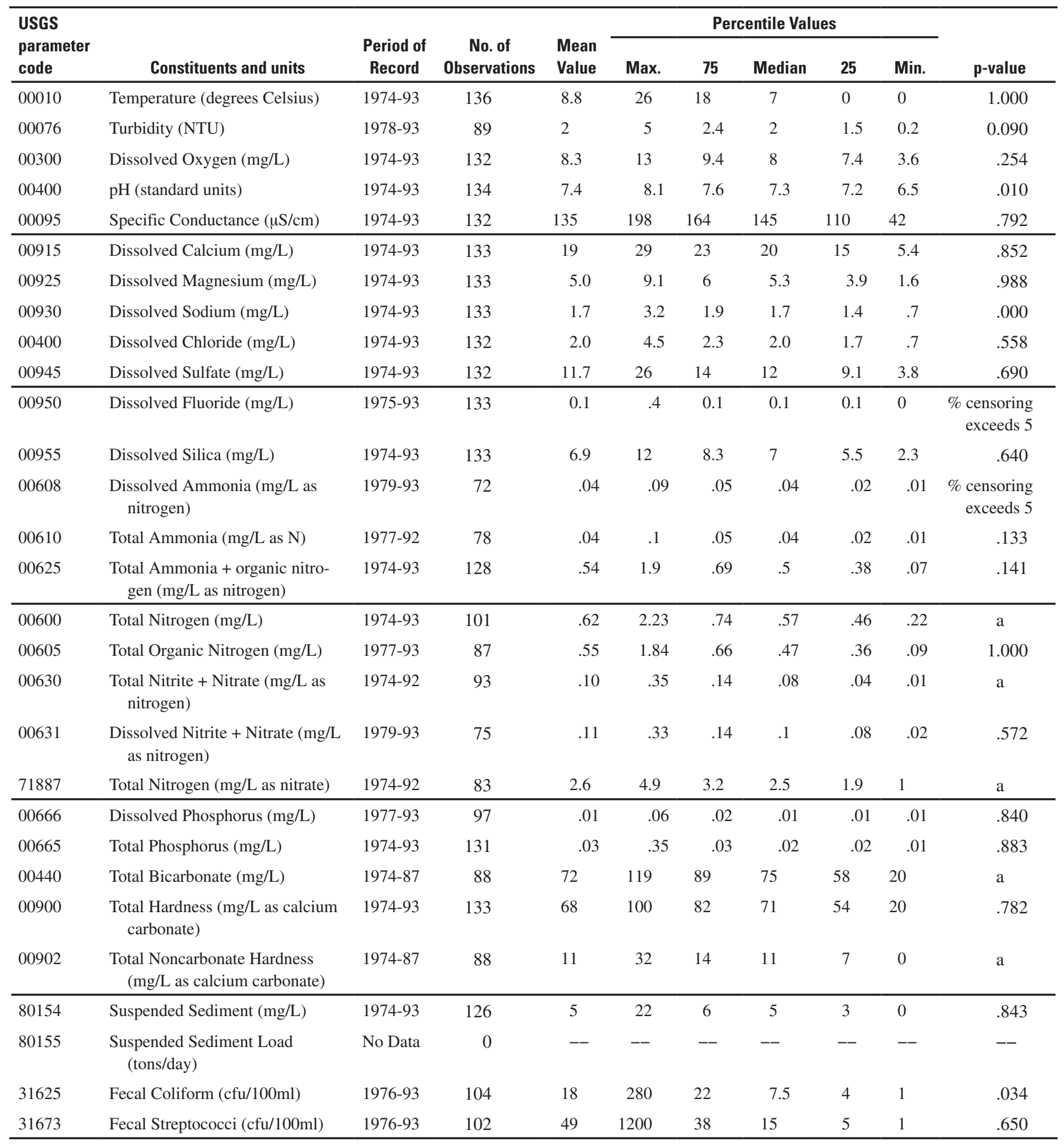





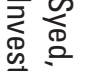

辛:

$\overline{0}$

o 8

吾

זִ

?

댕

क्ष

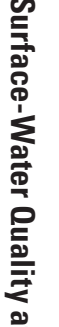

$\infty$

$\frac{\mathscr{\Phi}}{\mathbb{8}}$

$\stackrel{0}{\frac{1}{8}}$

$\frac{\pi}{2}$

空

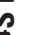

垔

$\exists$

(2)

$\sum_{2}^{2}$

9 Printed on recycled paper 